Preprints of the

Max Planck Institute for

Research on Collective Goods

Bonn 2011/3

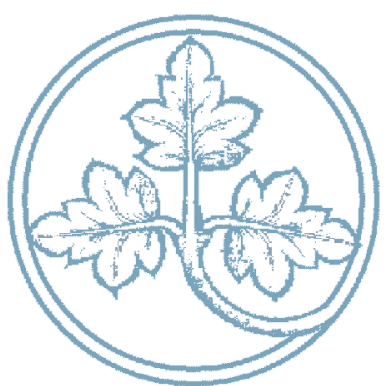

Antitrust Law and the

Promotion of Democracy and Economic Growth

Niels Petersen

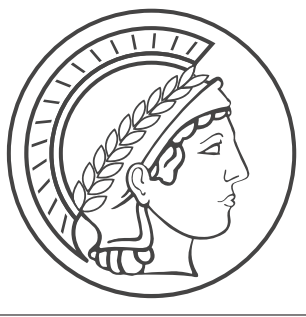




\section{Antitrust Law and the Promotion of Democracy and Economic Growth}

Niels Petersen

January 2011 


\title{
Antitrust Law and the Promotion of Democracy and Economic Growth
}

\author{
Niels Petersen
}

\begin{abstract}
There is a considerable debate in the legal literature about the purpose of antitrust institutions. Some argue that antitrust law merely serves the purpose of economic growth, while others have a broader perspective on the function of antitrust, maintaining that the prevention of economic concentration is an important means to promote democratization and democratic stability. This contribution seeks to test the empirical assumptions of this normative debate. Using panel data of 154 states from 1960 to 2007, it analyzes whether antitrust law actually has a positive effect on democracy and economic growth. The paper finds that antitrust law has a strongly positive effect on the level of GDP per capita and economic growth. However, there is no significant positive effect on the level of democracy. It is suggested that these results might be due to the current structure of existing antitrust laws, which are designed to promote economic efficiency rather than to prevent economic concentration.
\end{abstract}




\section{Introduction}

According to standard economic theory, competition is a crucial element for the functioning of markets. If there is no sufficient competition either on the demand or on the supply side, some market participants may obtain dominant market positions that allow them to set prices in their favor, impeding an efficient allocation of goods. Therefore, many national economies establish special antitrust institutions seeking to prevent the emergence of monopolies or cartels and thus guaranteeing sufficient market competition. Despite this fundamentally economic rationale, there is a fierce debate in legal scholarship about the normative foundations and goals of antitrust law. Orthodox theory claims that the promotion of economic efficiency was the exclusive aim of antitrust regimes (Bork 1993). Other scholars agree on the economic aim of antitrust law, but have a more distributive understanding of its functions (Akman 2009).

However, not everyone believes that antitrust law has an exclusively economic function. Some prominent scholars try to establish a link between antitrust law and the promotion of democracy. This strand of thought developed because of the conviction that business cartels played a crucial role in the rise to power of the Nazi regime in Germany (Gerber 1994: 28-29). For this reason, the effect of cartelization on the political landscape in Weimar Germany prompted the Americans to force Germany to adopt an effective antitrust regime after the end of the Second World War (Quack and Djelic 2005: 258-59) and gave rise to the influential Freiburg School that shaped economic and political thinking in post-war Germany.

However, the idea that antitrust law may have a positive effect on the stability of democracy is not limited to Germany. Many North American scholars also highlight the connection between the two fields. Most prominently, Milton Friedman (1962: 16) argues that the dispersion of economic power is a necessary counterbalance to the centralization of political power in the government. Some legal scholars also point out the positive effect of antitrust law for democracy and advocate a stronger democratic interpretation of antitrust practices (Adams 1979; Green 1987; Barnes 1989: 809-28).

The debate on the foundations of antitrust law has, so far, been almost exclusively normative. There have been few empirical analyses on whether antitrust law actually promotes economic development or democracy. This study aims at filling this void. After a short review of the empirical literature on this issue, the paper will first deal with the relationship between antitrust law and economic growth and democracy on a theoretical level. The relationship between antitrust law and economic growth seems to be straightforward, as the better functioning of economic markets should also enhance general welfare.

In contrast, a potential positive effect of the existence of an antitrust institution on democracy seems to be more counterintuitive. The argument consists of two steps. First, it is argued that antitrust law contributes to preventing an overly strong concentration of economic resources within a society. Second, a deconcentration of economic resources makes it more likely that a society will make the transition to a democracy and it stabilizes a democracy once it is estab- 
lished. This is due to two reasons: on the one hand, the dispersion of resources leads to a societal balance of power. On the other hand, the incentives of economic elites to oppose democracy are the stronger the greater the cleavage of wealth is in a society.

The quantitative analysis is based on panel data of 154 states from 1960 to 2007. It finds that the introduction of an antitrust regime has a strongly significant positive effect on economic development and growth. However, it does not find a significant positive effect of antitrust law on the level of democracy. The concluding part of the paper, finally, deals with several explanations for why there is no positive finding on the relationship between antitrust law and democracy. It suggests that this might be due to the currently prevalent structure of antitrust law, which focuses not on economic concentration as such, but rather on concentration in particular markets.

\section{The Empirical Literature}

The empirical evidence on the effects of antitrust law is scarce. There is some empirical evidence on the effects of antitrust regimes (1.). However, there are no studies on the relationship of competition and democracy. But there are several studies analyzing different factors that are supposed to enhance the quality of democracy (2.)

\section{The Effects of Antitrust Regimes}

Although, there have not been any attempts so far to analyze the relationship between antitrust regimes and democracy empirically, there are several empirical studies on measuring the effectiveness of antitrust regimes. The main focus of these studies is the effect of antitrust laws on economic indicators, such as economic growth, productivity or the level of competition. There are several empirical studies that try to establish that competition has a positive effect on economic growth (Dutz and Hayri 2000) and welfare (Baker 2003). While Baker's conclusions are based on historical case studies, Dutz and Hayri make a cross-sectional analysis of different countries using various indicators for the intensity of the competition. They do, however, not address whether the analyzed countries actually have an antitrust institution. Some studies also show opposing trends. With several case studies Robert Crandall and Clifford Winston (2003) try to show that antitrust regulation does not influence the development of market prices and does not, thus, enhance consumer welfare. ${ }^{1}$ Furthermore, Hiau Looi Kee and Bernard Hoekman (2007) found in an econometric analysis that there is no significant effect of the presence of an antitrust law on the actual level of competition.

While the aforementioned studies either focus on the actual level of competition or the mere presence of competition law, there are also analyses that try to qualify the institutional quality of

1 See also the historical analysis of Carsten Burhop and Thorsten Lübbers, who show that the cartelization of the German coal industry before the First World War did not have a significant effect on the productive efficiency of the industry (Burhop and Lübbers 2009). 
antitrust regimes and to measure whether the institutional quality has an effect on the actual level of competition or economic growth. Michael Krakowski (2002) analyzed the effect of the experience of a competition agency and found that the level of competition increases the longer a competition agency has been in place.

Some studies try to evaluate the scope of the antitrust regime and to see whether the scope has an effect on the level of competition. Michael Nicholson (2008) develops an Antitrust Law Index (ALI) that measures the scope of different competition law regimes. He focuses on the "law in the books' and analyzes three dimensions of antitrust law: regime structure, merger policy and anticompetitive practices (Nicholson 2008: 1019). He analyzes whether a competition regime possesses certain formal characteristics and awards one or two points if these characteristics exist. He finds, however, that nominally strong antitrust regimes do not necessarily lead to a high level of competition. This result is confirmed by Keith Hylton and Fei Deng (2007), who basically use the same index and find that there is no statistically significant positive relationship between the nominal scope of the competition regime and the actual level of competition.

The previous two studies tried to evaluate the antitrust law 'in the books', i.e., the strength of the regime, as it presents itself from the legal texts. However, there is always a significant gap between the nominal provisions and the actual implementation of the provisions in practice. Two further studies try to take this difference into account by looking at the actual practice of different antitrust regimes. Mark Dutz and Maria Vagliasindi (2000) evaluate the effectiveness of antitrust regimes in transition economies of Eastern Europe and the former Soviet Union based on an analysis of their practice. They code the different regimes based on the level of law enforcement, competition advocacy and institutional-related activities (Dutz and Vagliasindi 2000: 765). Using a cross-sectional data set, they find that the quality of the antitrust regime has a positive effect on the level of competition in the observed countries.

Stefan Voigt (2009) equally proposes an indicator for the effectiveness of antitrust regimes that is not merely based on the 'law in the books', but also takes the actual institutional practice into account. Based on a survey of the practice of various antitrust agencies, he comes up with indicators for the formal basis of the regime, the use of economic methods, the de jure and the de facto independence. He finds that both, the de jure and the de facto independence of the antitrust agency have a positive effect on the total factor productivity of a country.

\section{The Conditions Enhancing the Quality of Democracy}

There is an intense discussion in comparative politics and economics on which factors facilitate the transition to democracy or strengthen a democracy once it has been established. There are two strands of this discussion. Some scholars rather focus on the socio-economic environment that enhances the quality of democracy, while others analyze the behavior and the incentives of political elites and times of regime transition. The first and most prominent approach from the socio-economic perspective was modernization theory, according to which the level of economic 
development has a positive effect on the quality of democracy in a country (Lipset 1959). This positive relationship between economic development and democratization has been confirmed in several empirical studies (Bollen 1979; Bollen and Jackman 1985; Diamond 1992; Londregan and Poole 1996; Barro 1996, 1999; Boix and Stokes 2003; Epstein et al. 2006). It is supposed to be observed because a higher level of economic development leads to a higher level of education and a more diversified society. The diversification leads to a greater demand for institutions that tolerate pluralism, and education teaches tolerance for pluralistic values. Both factors should enhance the demand for democratic governance (Lipset 1959: 78-85).

However, some authors have raised doubts about the empirical relationship between economic development and democracy. The mere existence of a correlation between the two factors does not mean that economic development causes transition to democracy (Przeworski and Limongi 1997). Causation may also run into the other direction, or both factors may be caused at the same time by certain historical determinants (Acemoglu et al. 2008). Therefore, Adam Przeworski and colleagues have proposed a reduced version of the relationship between economic development and democracy: while economic development does not increase the likelihood of a transition to democracy, it stabilizes democracy once it has been established (Przeworski et al. 2000: 92106). ${ }^{2}$

But there are also alternative explanations of why democracies emerge and persist. Tatu Vanhanen (1990) argues that democratization depends on the distribution of power-resources. The more centralized power-resources are, the easier it is to suppress the majority population and thus to prevent a transition to democracy. Other authors also focus on distributive issues, but rather concentrate on the distribution of material wealth. According to Carles Boix (2003), transition to democracy depends on the distribution of wealth and capital mobility. The more distributed wealth is, the less the wealthy elites of a country have to fear the redistributive effect of democracy. Even if there is a high concentration of wealth, democracy may nevertheless be implemented if capital is mobile, so that the elites have the opportunity to evade taxes by bringing their fortunes abroad.

Daron Acemoglu and James Robinson (2006) also refer to wealth distribution as a key factor for the quality of democracy. They argue that we observe greater interdependencies in industrialized societies with greater material equality. In such societies, physical repression is much more costly for the wealthy elites, which increases the likelihood of democracy. Finally, there are some cultural explanations, which argue that the stability of democracy is dependent on the internalization of democratic values by the population and the political elites (Almond and Verba 1963; Diamond and Linz 1989). This internalization of democratic values is enhanced by experience with democracy. The more experience a country has with democratic governance, the more likely it is that it will sustain democracy (Persson and Tabellini 2009).

2 But see the critique of Przeworski et al. (2000) that is voiced by Boix and Stokes (2003) and Epstein et al. (2006). 
The actor-centric approaches analyze the incentives of the economic, political and societal elites who can influence the political fate of a country in times of transition. According to this perspective, democracy will usually be established if none of several competing groups of the elite has a clear advantage so that the procedural insecurity introduced by democracy seems to be the best option (Przeworski 1986; Sørensen 1998). Furthermore, Bruce Bueno de Mesquita and colleagues (2002) argue that the size of the electorate, i.e., the members of the elite with potential political influence, is decisive for the stability of an autocracy. The bigger the electorate, the more instable is an autocracy, and the more likely is a transition to democracy.

\section{Antitrust and the Promotion of Economic Development and Democracy}

This section will take a closer look at the causal mechanism of why antitrust law is supposed to promote democracy and economic development. It will first give a short account on the emergence of antitrust regimes (1.) before analyzing the relationship of antitrust law and democracy (2.) and economic growth (3.) in more detail.

\section{The Emergence of Antitrust Institutions}

For more than a half century, antitrust law was an exclusively North American affair. Canada and the United States introduced their antitrust legislation at the end of the $19^{\text {th }}$ century and were for long the only states on this path. After World War II, Japan and some European countries followed. However, it was not before the 1990s that antitrust laws became a common phenomenon that can be found in all regions of the world (see figure 1). Today, more than half of the member states of the United Nations have an antitrust institution. The reasons for countries to introduce an antitrust law differ. Some countries had internal reasons, introducing antitrust legislation as part of an economic reform. Others reacted to external pressure by international institutions, such as the European Union or the World Bank. I will highlight two examples in order to show the different paths that countries have taken to establish competition institutions - South Korea and Senegal.

South Korea introduced antitrust legislation in 1980 by adopting the Monopoly Regulation and Fair Trade Act. ${ }^{3}$ The Korean economy had experienced substantial growth in the 1960s and 1970s (see figure 2), during which it developed from an agricultural to an industrial and commercial economy. This economic transformation led to a considerable concentration of economic power in the hands of a few business conglomerations, known as 'chaebol'. The emergence of these chaebol was aided by the Korean government because it was thought that taking advantage of economies of scale would promote economic development. In the 1970s, however, many observers came to the conclusion that this concentration of economic power harmed the competi- 
tiveness of the Korean economy. When the country experienced an economic slowdown in the late 1970s, the government changed its attitude towards the chaebol and tried to limit their economic power. The introduction of the 1980 antitrust law was thus one piece of the strategy of disempowering the Korean business conglomerates.

Senegal suffered a phase of significant economic contraction in the early 1990s (see figure 3). As a reaction to this economic downturn, the country implemented an economic reform program in 1994 under a World Bank initiative in order to liberalize its economy. The introduction of a modern competition and antitrust law was one part of the reform program, whose cornerstone was the devaluation of the currency (Clement et al. 2001: 19). The law was not implemented before the summer of 1996, when the Competition Commission was created and the Commissioners were officially appointed. But even thereafter, the Commission was underfunded and the regime basically ineffective. However, at the end of the 1990s, the Senegalese government realized that some economic sectors were working in a dysfunctional manner because of competition issues, so that they made serious efforts to make the antitrust system more effective (Clement et al. 2001: 20-22).

\section{The Causal Mechanism: Antitrust Law and Democracy}

The theoretical argument on why the establishment of an antitrust regime should have a positive effect on the quality of democracy has two steps. First, antitrust regimes are supposed to prevent the concentration of economic power in the hands of a few. In a competitive market, a product will be offered at a price based on the competition between different suppliers. In a monopolized or cartelized economy, the producer of a good or the provider of a service has the ability to determine the price independently. There are no competitors who will undercut the price if it is too high. Therefore, a monopolist or a cartel will reap a greater benefit from offering her product at a higher price than she would in a competitive market. Consequently, the supplier side keeps a bigger share of the transactions than it would in a competitive market. In contrast to cartels, monopolies have a second way to enhance economic concentration. They are simply the only players in the specific market sector. If there were more than one player, the economic benefits of supplying the market would not be concentrated in one hand.

Second, economic deconcentration increases the likelihood that a country will either transition to democracy, or it strengthens the stability of an already established democracy. This argument has two dimensions: on the one hand, economic elites have to have the power to influence politics, and this influence is the greater the higher the concentration of economic wealth is. On the other hand, economic and political elites must have incentives to allow a transition to democracy or not to oppose an already existing democracy if there is a higher level of material equality.

Political authority does not exist in a vacuum. It rests on power, and this power is dependent on resources. Autocratic regimes can thus not sustain themselves. Instead, they need military and police forces, money to pay these forces, information, media, machines and scientific-technical 
knowledge (Tilly 2007: 116) in order to be able to rule the country. Therefore, they need the support of the economic elites, who supply them with all these means. The greater the size of the group of supporters is, the more instable this group will be. The more concentrated the necessary resources are in the hands of a few, the more stable is the autocratic regime (Bueno de Mesquita et al. 2002).

Democracy is generally understood as a political system that broadens the selectorate, i.e., the group of people who can exert political power. If economic wealth is concentrated in the hands of a few and if the non-wealthy possess the majority of votes in the democratic decision-making process, then democracy often has a redistributive effect. The poor majority will use their votes to establish redistributive institutions. ${ }^{4}$ Therefore, the wealthy elites will oppose democracy as long as the costs of suppressing the population are below the costs of redistributive politics. Consequently, increasing material equality leads to less redistributive pressure and thus decreases the costs of democracy for wealthy elites (Boix 2003). At the same time, it increases the costs of oppression as a more differentiated economy leads to more interdependence between the different societal groups (Acemoglu and Robinson 2006).

\section{The Effect of Antitrust Law on Economic Development}

Standard economic theory argues that antitrust law promotes economic welfare because it guarantees a certain level of competition und thus enhances the functioning of market mechanisms. Markets work better if there is a considerable number of suppliers and consumers, which gives market participants a certain choice. If the number of market actors is too small, the functioning of the market is restrained, which leads to a loss in economic efficiency. Prices are usually higher in markets with restrained competition than they would be in situations of full competition. This leads to a so-called deadweight loss in markets in which demand increases with decreasing prices because more consumers would buy the product if the price were lower (Harberger 1964). However, the deadweight loss is not the only reason why economic concentration in markets leads to a decrease of economic welfare. As companies can extract high rents out of monopolies, they have strong incentives to invest in the fight for a monopoly and the defense of such a monopoly once they have established it (Tullock 1967). The means that are invested into this fight against competitors do not have any economic benefit and thus impede economic efficiency (Tullock 1967: 228). elites have more means to organize themselves, to make their interests heard in the political process and even to frame certain matters in such a way that their interests are seemingly aligned with the interests of the poor and the middle class (Shapiro 2006: 104-45). However, the experience of the European welfare state shows that democracy may very well have redistributive effects. 


\section{The Research Design}

The question of the effect of antitrust law on democracy and economic development will be studied using panel data of 154 countries from 1960 to 2007..$^{5}$ In this section, I will explain the research design of the study. One of the dependent variables, democracy, and our main explanatory variable, the existence of an antitrust regime, are, to a certain extent, qualitative concepts. We thus have to find a way to transform qualitative observations into quantitative data. I will address this challenge both for democracy (1.) and for the existence of an antitrust regime (2.). Furthermore, it is the aim of the study to test a causal claim - does the existence of an antitrust regime make a difference for economic development and democracy? There are two challenges that have to be addressed in this respect. First, we have to control for the causal direction of the effect. It is plausible that democracy and economic development are not only enhanced by antitrust law, but that economically developed and democratic countries are also more likely to introduce antitrust institutions. If we find a correlation between both factors, we do not know the direction of the causal effect so that we also have to control for the endogeneity of the explanatory variable (3.). Second, we have to make sure that the effects that we observe are not spurious, i.e., that the effect of antitrust on economic development and democracy is not due to a third, unobserved factor. Therefore, we have to include appropriate control variables into our model (4.).

\section{The Quality of Democracy}

The definition of the concept of democracy is highly debated. One of the disagreements is whether democracy is a binary or a gradual concept. According to a binary understanding of democracy, a political system is either democratic, or it is not - there is neither a space in between these two situations, nor can democracy have different qualities. Such a binary understanding is used in many empirical studies of democracy. Following Adam Przeworski and colleagues (2000), there are several contributions that use a binary definition of democracy (Boix 2003; Boix and Stokes 2003; Epstein et al. 2006). According to Przeworski and colleagues (2000: 15), a country is democratic if the chief executive body and the seats in the effective legislative body were either directly or indirectly filled by contested elections. Elections are considered to be contested if their outcome is uncertain ex-ante, irreversible ex-post, and if they are held repeatedly (Przeworski et al. 2000: 16).

The alternative is to define democracy gradually. According to the gradual definition, democracy is not just an either-/or-concept, but there can also be democracies of different quality. While democracy certainly has a binary component, as we still need to distinguish democracies from non-democracies, it is useful for the purpose of our analysis to add a gradual dimension to the definition of democracy. ${ }^{6}$ If we look at the negative influences that the concentration of economic power can have on democratic politics, not all of them have to lead to a total breakdown of

$5 \quad$ For a list of the included countries, see Appendix B.

6 On the dual nature of democracy as binary and gradual concept, see Sartori 1987; Bogdandy 2001. 
democracy. Instead, the decrease of the quality of democracy might be expressed by a strengthening of executive powers at the expense of the legislature, an erosion of the rule of law or the limitation of civil liberties. Such changes cannot be grasped by a binary measure of democracy. Therefore, this study adopts a gradual conception. Increases in quality are not only transitions to democracy, but also an increase of the institutional quality of an already existing democracy. In order to measure the quality of democracy, I will use the Polity IV-score, which codes political systems based on three different characteristics - executive recruitment, the constraints on the execution of executive power and the amount of political competition (Marshall and Jaggers 2009).

\section{The Measurement of Antitrust Law}

Measuring the existence of an antitrust regime seems, at first glance, to be a rather simple exercise. We can observe whether and when an antitrust law was introduced in the countries of our data set and use a binary code to distinguish between the two states of the world - a one for the existence of an antitrust regime and a zero otherwise. However, such a binary coding only tells us whether such antitrust institutions exist in the books. It does not tell us anything about the effectiveness of the regime. Even though certain countries may have established antitrust institutions, these institutions might be ineffective because they lack sufficient funds to carry out their work or because their operation is impeded by political actors following different interests.

We could try to solve this problem by finding a measure for the effectiveness of antitrust regimes. There have been some proposals in the legal and economic literature to quantify the effectiveness of antitrust laws. Michael Nicholson (2008) develops an Antitrust Law Index (ALI) that measures the scope of different competition law regimes. He focuses on the 'law in the books' and analyzes three dimensions of antitrust law: regime structure, merger policy and anticompetitive practices (Nicholson 2008: 1019). He analyzes whether a competition regime possesses certain formal characteristics and awards one or two points if these characteristics exist. If there are, e.g., prison sentences as possible sanctions or if there is the possibility of private enforcement of competition provisions, then a certain competition regime will be awarded one point. In the end, Nicholson can classify every competition regime on a scale from zero to 29 with zero being the least and 29 the most effective.

However, Nicholson only deals with the 'law in the books' and is not concerned with its implementation. There are often decisive differences between the 'law in the books' and the law in action, though. In some cases, legal provisions are not implemented at all or very sparely. In other cases, the legal practice looks different than one would assume from just reading the legal texts. It can therefore be argued that public policy and the general socio-economic approach are more decisive factors for the effectiveness of antitrust law than its actual formal scope (Gal 2004: 26). 
Stefan Voigt (2009) tries do deal with this problem by setting up an index that measures the effectiveness of an antitrust regime in practice. Based on questionnaires that he sent to antitrust authorities, he comes up with scores for the de jure and the de facto independence of these antitrust authorities. While these scores are probably better proxies for the effectiveness of an antitrust regime than the mere formal evaluation of the 'law in the books', the index has some practical disadvantages. It does not consist of time-series data, so that it allows only cross-sectional analyses. However, we need time-series data in order to cope with the endogeneity problem and to track long-term effects of antitrust law.

Instead of trying to evaluate the quality of antitrust regimes, we can also look at their effects in order to find proxies for their effectiveness. One common way to measure the effectiveness of antitrust institutions is to take survey data from the World Economic Forum on the perceived effectiveness of the antimonopoly policy. In the survey, several executives are asked about what they think about how effective the antimonopoly policy in their country is. This survey has two disadvantages. First, there is probably considerable measurement error, so that it is only a vague proxy for the effectiveness of an antitrust regime. The data shows a high volatility of the score for the same country between different years, which suggests that it is probably not a reliable measure. Second, although there is data available over time, the time span is very short. The maximum is ten years for one country; and for most countries, it does not exceed two or three years.

This discussion shows that there is no perfect way to measure the existence of an effective antitrust regime. Therefore, this study will take a mixed approach. It will estimate different models with differing proxies for the existence of an antitrust regime as main explanatory variable. The basic model will contain a binary variable that just indicates whether an antitrust regime exists. As pointed out, this binary measure may have some measurement error. But this measurement error will only run in one direction. It is possible that some countries are coded as having an antitrust institution, although the antitrust regime is ineffective. Our coefficient might thus have a downward bias and show a smaller effect than we would find if we could perfectly measure the effectiveness of an antitrust system. If we find a significant effect, this effect will thus not be due to measurement error.

However, I will contrast these results with the results of a second model that will use the score of Nicholson's antitrust law index as main explanatory variable in order to see whether such an index based on formal characteristics is a better measure of the effectiveness of an antitrust institution than the mere binary coding. Furthermore, it is assumed that it takes some time after the introduction of an antitrust law until this institutional change has some visible effect either on the political order or on economic development. The antitrust institution has to be established, it has to perform investigations and take decisions. This is a process that will not happen over night. Therefore, the basic model will be run in three different versions - with the antitrust variable as three-, five- and ten-year lag. 


\section{The Model and the Endogeneity Problem}

There are two points in specifying the model that have to be treated more in depth. Following Daron Acemoglu and colleagues (2008), I assume that there are time-invariant unobservables that affect the political system as well as economic development and the introduction of an antitrust law. An example for such an unobservable would be the culture of a country. ${ }^{7}$ In order to control for these time-invariant unobservables, I will use a fixed effects model. Furthermore, if we analyze the relationship between the existence of antitrust law and democracy, causation might not only run into one direction. If countries with an antitrust regime are more democratic, this might be due to a democratizing effect of antitrust law. But it might also be because democracies are more likely to establish an antitrust institution. If we assume that wealthy elites and large, influential businesses have a tendency to oppose democracy because it has redistributive effects, then they will also have strong incentives to oppose an institution that seeks to counterbalance economic concentration (Gerber 2006: 1196). Figure 4 shows the development of the democracy score of countries from ten years before the introduction of an antitrust regime to ten years after the introduction and compares it to the development of the democracy scores of countries that have not introduced an antitrust law to date. At the date of the introduction of the antitrust law, the democracy score of the countries introducing the system is significantly higher than of countries that do not introduce it. The same is true for economic development. States introducing an antitrust law are significantly more developed economically than states without an antitrust law (figure 5$)^{8}$

A first step to cope with the endogeneity problem is to analyze lags of the independent variables. The political system at point $t$ cannot be the reason for why a country introduced an antitrust law at $\mathrm{t}-1$. However, just introducing lags will not do the trick because such a model may have an omitted variable bias. Although the introduction of an antitrust law at $\mathrm{t}-1$ is not dependent on the political system at $\mathrm{t}$, it may be caused by the political system at $\mathrm{t}-1$. The latter is itself an influential reason for the political system we observe at $t$. Therefore, we have to introduce a lag of the dependent variable into our equation and estimate a dynamic model. For measuring the effect of antitrust on democracy, it will have the following form:

$$
\mathrm{d}_{\mathrm{it}}=\alpha \mathrm{d}_{\mathrm{it}-3}+\gamma \mathrm{c}_{\mathrm{it}-3}+\mathbf{x}_{\mathrm{it}-3}^{\prime} \boldsymbol{\beta}+\mathrm{v}_{\mathrm{i}}+\mathrm{u}_{\mathrm{it}}
$$

where $d_{i t}$ is the democracy score for each country $i$ in period t. The lagged value of $d$ on the right-hand side of the equation is supposed to capture the mentioned persistence of democracy. The variable $c_{i t-3}$ is the main explanatory variable, i.e., the existence of an antitrust regime. The vector $\mathrm{x}_{\mathrm{it}-3}$ includes all control variables of the model. The variable $v_{\mathrm{i}}$ captures the fixed effects

7 Certainly, culture is not completely time-invariant, but may change over time. However, the change of culture is extremely slow, so that it seems justified to treat it as time-invariant. Furthermore, there are some empirical studies that try to proxy culture by using religion as a control variable (see, e.g. Przeworski et al. 2000; Boix 2003). However, these studies all rely on the data of La Porta et al. (1999), which is a static measure measuring the religious composition at only one point in time. Thus, they treat culture as if it were time-invariant.

See also Palim 1998. 
of each country, and $u_{i t}$ is the error term. The independent variables are lagged three times in order to model the long-term effect of the introduction of antitrust law on the political system. The model measuring the effect of antitrust law on economic development looks correspondingly:

$$
\operatorname{econ}_{i t}=\alpha \operatorname{econ}_{i t-3}+\gamma c_{i t-3}+\mathbf{x}^{\prime}{ }_{i t-3} \beta+v_{i}+u_{i t}
$$

where econ ${ }_{i t}$ is a measure of the GDP per capita of country $i$ in period $t$. In order to have a better sense of the relationship between antitrust policy and economic development, I will not only analyze the effect on the absolute level of GDP per capita, but also on economic growth. For this estimation, the following model will be used:

$$
\mathrm{gr}_{\mathrm{it}}=\gamma \mathrm{c}_{\mathrm{it}-3}+\mathbf{x}_{\mathrm{it}-3}^{\prime} \boldsymbol{\beta}+\mathrm{v}_{\mathrm{i}}+\mathrm{u}_{\mathrm{it}}
$$

where $\mathrm{gr}_{\mathrm{it}}$ is the average rate of economic growth per capita of the last three years. Therefore, $\mathrm{gr}_{\mathrm{it}}$ for $\mathrm{t}=2000$ consists of the average of the growth rates from 1998-2000. Note that I have not included a lag of the dependent variable on the right-hand side of the equation, as I do not assume that there is an endogeneity problem in this case. The introduction of an antitrust system may depend on the absolute level of economic development, but it is unlikely to depend on the growth rate per capita.

If we estimate the two dynamic models using a within-fixed-effects estimator, our estimates will be inconsistent. The within estimator eliminates $v_{i}$ from the equation by subtracting the individual country mean from each observation. Therefore, it requires that the error term $u_{i t}$ is uncorrelated with all explanatory variables:

$$
\mathrm{E}\left(\mathrm{u}_{\mathrm{it}} \mid \mathrm{x}_{\mathrm{i} 1}, \ldots, \mathrm{x}_{\mathrm{it}}, \ldots, \mathrm{x}_{\mathrm{iT}}\right)=0
$$

However, as the dynamic model contains a lag of the dependent variable on the right-hand side of the equation, this requirement is not met because future values of the lagged dependent variable are correlated with the error term. Therefore, we have to estimate our model using the first difference:

$$
\left(d_{i t}-d_{i t-1}\right)=\alpha\left(d_{i t-3}-d_{i t-4}\right)+\gamma\left(c_{i t-3}-c_{i t-4}\right)+\left(\mathbf{x}^{\prime}{ }_{i t-3}-\mathbf{x}^{\prime}{ }_{i t-4}\right) \beta+\left(u_{i t}-u_{i t-1}\right)
$$

This model can also be written as:

$$
\Delta \mathrm{d}_{\mathrm{it}}=\alpha \Delta \mathrm{d}_{\mathrm{it}-3}+\gamma \Delta \mathrm{c}_{\mathrm{it}-3}+\Delta \mathbf{x}^{\prime}{ }_{\mathrm{it}-3} \beta+\Delta \mathrm{u}_{\mathrm{it}}
$$

The corresponding model for estimating the effect of antitrust on the economic performance has the following form:

$$
\Delta \mathrm{econ}_{\mathrm{it}}=\alpha \Delta \mathrm{econ}_{\mathrm{it}-3}+\gamma \Delta \mathrm{c}_{\mathrm{it}-3}+\Delta \mathbf{x}^{\prime}{ }_{\mathrm{it}-3} \boldsymbol{\beta}+\Delta \mathrm{u}_{\mathrm{it}}
$$

Note that the base model contains the third lag of the dependent variable on the right-hand side of the equation. Therefore, the variable is not automatically correlated with the error term $\Delta u_{i t}$, as the latter only consists of $\left(u_{i t}-u_{i t-1}\right)$, but does not include $u_{i t-3}$. 
Table 1: Summary Statistics

\begin{tabular}{lccccc}
\hline \hline & Mean & Std. Dev. & Min. & Max. & $\mathrm{N}$ \\
\hline Democracy & .40 & 7.51 & -10 & 10 & 6461 \\
Log GDP per capita & 8.38 & 1.15 & 5.03 & 11.49 & 6398 \\
Antitrust & .243 & .439 & 0 & 1 & 7067 \\
ALI & .140 & .291 & 0 & 1 & 5917 \\
Growth & 2.03 & 5.14 & -34.07 & 70.48 & 6007 \\
Resources exports & 23.98 & 29.14 & 0 & 100 & 4435 \\
Log population & 8.86 & 1.58 & 3.82 & 14.09 & 7440 \\
Int. Environment & .21 & 2.13 & -2.41 & 3.86 & 7440 \\
Log trade openness & 4.04 & .66 & .68 & 6.12 & 6415 \\
\hline
\end{tabular}

\section{The Control Variables}

While the fixed effects estimator controls for the time-invariant disturbances, there are several other, time-variant factors that have to be included in the model: ${ }^{9}$

GDP per capita: As already mentioned, there are a considerable number of scholars who claim that economic development has some positive effect on democratization and/or the stability of democracy. ${ }^{10}$ It is also plausible that high-income countries are more likely to introduce an antitrust institution because they may have more money to sustain such an institution.

Democracy: In the model which measures the effect on economic development, we will have to control for the level of democracy. On the one hand, it is often assumed that democracy has a positive effect on economic development; ${ }^{11}$ on the other, we have seen that democratic regimes are more likely to introduce an antitrust regime.

Trade openness: Trade openness should have a similar effect on economic development and democracy as the existence of an effective antitrust policy. The more open a country is for foreign trade, the greater the competition on the markets is within the country. Furthermore, countries that are open to international trade might, at the same time, be more likely to introduce an antitrust regime.

Population: One can hypothesize that the size of the population of a country has an influence on democracy, the level of economic development and the existence of a competition regime at the same time. The political environment is different in large countries, compared to small ones. Furthermore, countries with a large population can make use of economies of scale and are more interesting for foreign investment, which might give them an economic advantage. Finally, the market structure in large economies is different to that in small ones so that the perception of the necessity of an antimonopoly policy might be different (Gal 2003).

9 For the sources of these variables, see Appendix A.

10 See above, II 2.

11 See Przeworski et al. 2000; Persson and Tabellini 2006, 2007. 
International Environment: The model will also include the average democracy score of all countries in the same year as a proxy for the international political environment. The more democracies there are in the world, the more pressure lies on the remaining autocracies to democratize. Furthermore, we have seen that the introduction of antitrust regimes is often caused by external pressure and thus likely to depend on the international political environment as well. ${ }^{12}$

Resources: There is some research on the negative effect of natural resources on economic development and democracy - the so-called resource curse (Ross 1999; Sachs and Warner 2001). Furthermore, Carles Boix (2003) claims that elites in countries which heavily rely on resources, and where capital is thus less mobile, oppose the introduction of institutions that have a redistributive effect. Therefore, such countries should also be less likely to introduce an antitrust regime.

\section{Data Analysis and Discussion}

\section{Descriptive Statistics}

The data set comprises 154 countries during the period from 1960 to 2007. In 1960, 11 states already had an antitrust institution. During the observed time period, 81 countries introduced an antitrust system. ${ }^{13}$ One state, Georgia, introduced an antitrust law in 1996 and effectively abolished it again in 2005. Figures 4 and 5 show that states introducing an antitrust law usually have a higher democracy score and a higher level of economic development. However, this does not mean that only democracies introduce antitrust laws. There are 38 countries in the data set that introduced an antitrust law as non-democracies, i.e. having a democracy score of five or less. 26 of these countries even had a democracy score of less than zero when they introduced an antitrust institution. Nearly half of the non-democracies that introduced an antitrust law had a transition to democracy during the observation period, which is indicated by a democracy score of six or more.

Furthermore, there is some evidence that the effectiveness of an antitrust institution does not fully depend on the level of democracy of a country. There may be effective antitrust institutions in non-democracies as well as ineffective ones in democracies. I correlated the corresponding 2005 democracy scores of the countries that have an antitrust law with two indicators on the effectiveness of antitrust institutions of Stefan Voigt's (Voigt 2006, 2009) data set. There is a positive correlation, but this correlation is weaker than one might expect. The correlation between the democracy score with the de jure independence of an antitrust institution is $r=.144$, and the correlation of the democracy score with the de facto independence is $r=.196$. There are also individual examples of countries with a low democracy score and a rather effective antitrust institution, as well as the other way round. Uzbekistan, for example, has a democracy score of -9, but its antitrust institution scores .466 on the de jure and .82 on the de facto independence scale,

12 See above, III 1.

13 See Appendix 2. 
which both run from zero to one. In contrast, Argentina has a democracy score of 8 , but scores .362 on the de jure and .45 on the de facto independence scale.

\section{Results}

If we look at the effect of antitrust law on democracy, we find that there is almost no significant positive effect. Table 2 shows the results of the first difference estimator of the basic model with different specifications. The first three columns contain the results of a First Difference OLS regression and three-year lags of the independent variables. The difference between the individual columns is the lag of the antitrust variable - I have included a three-, a five- and a ten-year lag. The coefficient of the antitrust variable is slightly positive in all models, but insignificant for the three- and the ten-year lag. We find a weak significance $(\mathrm{p}<.1)$ for the five-year lag. However, theoretically it does not seem to be plausible for an antitrust institution only to have a positive effect five years after its introduction, but that this positive effect vanishes five years later. In order to test the robustness of the result for the five-year lag, I also ran the model with a fourand a six-year lag. In both cases, the coefficient of the antitrust variable is statistically not significant. ${ }^{14}$ The fourth column replaces the binary antitrust variable by a variable containing an evaluation of the effectiveness of the antitrust regime, using the antitrust law index (ALI) proposed by Michael Nicholson (2008) and Keith Hylton and Fei Deng (2007). The results do not change significantly compared to the binary measure. The coefficient is positive and has about the same size as the binary measures, but again it is insignificant. Therefore, it seems that antitrust law does not have a positive effect on democracy, contrary to our assumptions.

14 Coefficients: antitrustt- $4=.082$ (std. err.: .121); antitrustt- $6=-.085(.309)$. 


\begin{tabular}{|c|c|c|c|c|}
\hline & (1) & $(2)$ & (3) & (4) \\
\hline Democracyt-3 & $\begin{array}{c}-.105^{\star *} \\
(.035)\end{array}$ & $\begin{array}{l}-.105^{\star *} \\
(.034)\end{array}$ & $\begin{array}{c}-.117^{* *} \\
(.038)\end{array}$ & $\begin{array}{c}-.129^{* *} \\
(.039)\end{array}$ \\
\hline Antitrust $t_{-3}$ & $\begin{array}{l}.241 \\
(.300)\end{array}$ & & & \\
\hline Antitrust $_{t-5}$ & & $\begin{array}{l}.256^{+} \\
(.147)\end{array}$ & & \\
\hline Antitrust $_{\mathrm{t}-10}$ & & & $\begin{array}{l}.119 \\
(.090)\end{array}$ & \\
\hline$A L I_{t-3}$ & & & & $\begin{array}{l}.225 \\
(.406)\end{array}$ \\
\hline $\begin{array}{l}\text { Log GDP } \\
\text { per capita.t-3 }\end{array}$ & $\begin{array}{c}.263 \\
(.402)\end{array}$ & $\begin{array}{l}.269 \\
(.401)\end{array}$ & $\begin{array}{c}.287 \\
(.537)\end{array}$ & $\begin{array}{l}-.170 \\
(.424)\end{array}$ \\
\hline Resourcest-3 $_{\mathrm{t}}$ & $\begin{array}{l}-.003 \\
(.004)\end{array}$ & $\begin{array}{l}-.003 \\
(.004)\end{array}$ & $\begin{array}{l}-.005 \\
(.004)\end{array}$ & $\begin{array}{l}-.003 \\
(.004)\end{array}$ \\
\hline Log population $_{\mathrm{t}-3}$ & $\begin{array}{c}3.291^{* *} \\
(.974)\end{array}$ & $\begin{array}{c}3.297^{* *} \\
(.979)\end{array}$ & $\begin{array}{l}4.353^{\star *} \\
(1.196)\end{array}$ & $\begin{array}{l}3.916^{\star *} \\
(1.076)\end{array}$ \\
\hline Int. Environment $t_{-3}$ & $\begin{array}{l}.183^{*} \\
(.080)\end{array}$ & $\begin{array}{l}.183^{*} \\
(.080)\end{array}$ & $\begin{array}{l}.148^{*} \\
(.087)\end{array}$ & $\begin{array}{l}.264^{* *} \\
(.098)\end{array}$ \\
\hline Log trade openness $\mathrm{t}_{-3}$ & $\begin{array}{l}-.396 \\
(.422)\end{array}$ & $\begin{array}{l}-.401 \\
(.428)\end{array}$ & $\begin{array}{l}-.435 \\
(.437)\end{array}$ & $\begin{array}{l}-.539 \\
(.479)\end{array}$ \\
\hline Observations & 3649 & 3648 & 3306 & 2802 \\
\hline $\mathrm{R}^{2}$ & 0.02 & 0.02 & 0.02 & 0.02 \\
\hline
\end{tabular}

Notes: All specifications of the model are estimated using the first difference estimator. ${ }^{+} p<\left..1\right|^{*} p<\left..05\right|^{* *} p<.01$

In order to test whether this finding might be due to the composition of the data set or specification of the model, I made some robustness checks (table 3). First, I reduced the data set to all observations from 1990 onwards. With this reduced data set, the five-year lag of the competition variable has a weakly significant positive effect on democracy. However, the ten-year lag is, though positive, statistically insignificant. Again, I did some robustness checks, running the model with a four- and a six-year lag, both of which were insignificant. ${ }^{15}$ If we look at the consequences of the introduction of an antitrust law on democracy in states that were not democratic when they introduced an antitrust law (i.e., they had a democracy score of 5 or less), the effect is statistically insignificant.

15 Coefficients: antitrustt-4 $=.115(.193)$; antitrustt- $6=.278(.237)$. 
Table 3: Robustness Checks on the Effect of Antitrust Law on Democracy

\begin{tabular}{|c|c|c|c|c|c|c|}
\hline & $\begin{array}{c}\text { Data1990 } \\
\text { 5yr-lag }\end{array}$ & $\begin{array}{c}\text { Data1990 } \\
\text { 10yr-lag }\end{array}$ & $\begin{array}{l}\text { Data Au- } \\
\text { tocracies }\end{array}$ & $\begin{array}{c}\text { Exconst } \\
\text { 5yr-lag }\end{array}$ & $\begin{array}{l}\text { Exconst } \\
\text { 10yr-lag }\end{array}$ & $\begin{array}{c}\text { PolComp } \\
\text { 5yr-lag }\end{array}$ \\
\hline Democracy $_{t-3}$ & $\begin{array}{l}-.110 \\
(.079)\end{array}$ & $\begin{array}{l}-.030 \\
(.021)\end{array}$ & $\begin{array}{l}-.108 \\
(.037)\end{array}$ & & & \\
\hline Exec. Constraints $\mathrm{t}_{-3}$ & & & & $\begin{array}{l}-.089^{*} \\
(.040)\end{array}$ & $\begin{array}{l}-.097^{*} \\
(.044)\end{array}$ & \\
\hline Pol. Competition $\mathrm{t}_{\mathrm{t}-3}$ & & & & & & $\begin{array}{c}-.112^{\star \star} \\
(.043)\end{array}$ \\
\hline Antitrust $_{\mathrm{t}-5}$ & $\begin{array}{l}.433^{+} \\
(.220)\end{array}$ & & $\begin{array}{c}.092 \\
(.085)\end{array}$ & $\begin{array}{l}.081^{*} \\
(.040)\end{array}$ & & $\begin{array}{c}.085 \\
(.057)\end{array}$ \\
\hline Antitrust $_{\mathrm{t}-10}$ & & $\begin{array}{l}.202 \\
(.145)\end{array}$ & & & $\begin{array}{l}-.011 \\
(.029)\end{array}$ & \\
\hline Log GDP per capita.t-3 & $\begin{array}{l}1.221 \\
(.809)\end{array}$ & $\begin{array}{l}-.513 \\
(.613)\end{array}$ & $\begin{array}{c}.171 \\
(.399)\end{array}$ & $\begin{array}{c}.023 \\
(.143)\end{array}$ & $\begin{array}{c}.178 \\
(.152)\end{array}$ & $\begin{array}{l}-.217 \\
(.187)\end{array}$ \\
\hline Resources $_{\mathrm{t}-3}$ & $\begin{array}{l}-.003 \\
(.006)\end{array}$ & $\begin{array}{l}-.006^{+} \\
(.003)\end{array}$ & $\begin{array}{l}-.004 \\
(.003)\end{array}$ & $\begin{array}{l}-.001 \\
(.002)\end{array}$ & $\begin{array}{l}-.002 \\
(.002)\end{array}$ & $\begin{array}{c}.000 \\
(.002)\end{array}$ \\
\hline Log population $\mathrm{t}_{\mathrm{t}-3}$ & $\begin{array}{l}5.389^{+} \\
(2.816)\end{array}$ & $\begin{array}{c}2.739 \\
(2.378)\end{array}$ & $\begin{array}{l}3.088 \\
(.938)\end{array}$ & $\begin{array}{l}.044 \\
(.319)\end{array}$ & $\begin{array}{c}.481 \\
(.322)\end{array}$ & $\begin{array}{l}1.139^{*} \\
(.504)\end{array}$ \\
\hline Int. Environment $t_{t-3}$ & $\begin{array}{l}-.330 \\
(.256)\end{array}$ & $\begin{array}{c}.035 \\
(.249)\end{array}$ & $\begin{array}{l}.203^{*} \\
(.084)\end{array}$ & $\begin{array}{l}.101^{* *} \\
(.026)\end{array}$ & $\begin{array}{l}.080^{\star *} \\
(.027)\end{array}$ & $\begin{array}{l}.124^{* *} \\
(.036)\end{array}$ \\
\hline Log trade openness $\mathrm{t}_{-3}$ & $\begin{array}{l}-.226 \\
(.410)\end{array}$ & $\begin{array}{l}.189 \\
(.335)\end{array}$ & $\begin{array}{l}-.255 \\
(.368)\end{array}$ & $\begin{array}{l}-.098 \\
(.151)\end{array}$ & $\begin{array}{l}-.114 \\
(.153)\end{array}$ & $\begin{array}{l}-.195 \\
(.234)\end{array}$ \\
\hline Observations & 1311 & 840 & 3536 & 3486 & 3159 & 3486 \\
\hline
\end{tabular}

Notes: ${ }^{+} p<\left..1\right|^{*} p<\left..05\right|^{* *} p<.01$

Finally, I substituted the democracy score by some component variables in order to see whether an antitrust institution might not have a positive influence on democracy as such, but instead on certain institutions that form part of a stable democracy. On the one hand, I looked at the executive constraints variable that is included in the Polity IV-data set and measures the institutionalized constraints on the decision-making powers of chief executives (Marshall and Jaggers 2009: 23). I had hypothesized that a strong concentration of economic power would lead to less executive restraints. We find that the five-year lag of the antitrust variable has a statistically significant positive effect on the extent of executive restraints. However, the ten-year lag is statistically insignificant and even slightly negative. In order to test the robustness of the model with the fiveyear lag, I also tested the model with a four- and a six-year lag, and found that both were statistically insignificant. ${ }^{16}$ On the other hand, I looked at the effect of antitrust law on the level of political competition, i.e., the polcomp-variable of the Polity IV data set. With regard to this factor, the coefficient of the antitrust variable was statistically insignificant for all lag specifications.

16 Coefficients: antitrustt- $4=-.020(.012)$; antitrustt- $6=-.043(.122)$. 
Table 4: Effect of Antitrust Law on Economic Development

\begin{tabular}{|c|c|c|c|c|c|}
\hline & (1) & (2) & (3) & (4) & (5) \\
\hline Log GDP per capita-3 & $\begin{array}{l}.189^{* *} \\
(.041)\end{array}$ & $\begin{array}{l}.190^{\star \star} \\
(.042)\end{array}$ & $\begin{array}{l}.219^{\star *} \\
(.029)\end{array}$ & $\begin{array}{l}.188^{* *} \\
(.042)\end{array}$ & $\begin{array}{l}.172^{\star \star} \\
(.046)\end{array}$ \\
\hline Antitrust $_{\mathrm{t}-3}$ & $\begin{array}{l}.020^{* *} \\
(.006)\end{array}$ & & & $\begin{array}{l}-.075^{+} \\
(.043)\end{array}$ & \\
\hline Antitrust $_{t-5}$ & & $\begin{array}{l}.021^{* *} \\
(.005)\end{array}$ & & & \\
\hline Antitrust $\mathrm{t}_{\mathrm{t}-10}$ & & & $\begin{array}{l}.026^{\star *} \\
(.010)\end{array}$ & & \\
\hline $\mathrm{ALI}_{\mathrm{t}-3}$ & & & & & $\begin{array}{l}.026^{*} \\
(.012)\end{array}$ \\
\hline Democracy.t-3 $_{\text {- }}$ & $\begin{array}{l}.0009 \\
(.0006)\end{array}$ & $\begin{array}{l}.0009 \\
(.0006)\end{array}$ & $\begin{array}{l}.0012^{*} \\
(.0006)\end{array}$ & $\begin{array}{l}.0006 \\
(.0006)\end{array}$ & $\begin{array}{l}.0007 \\
(.0006)\end{array}$ \\
\hline Resourcest-3 & $\begin{array}{l}-.0001 \\
(.0002)\end{array}$ & $\begin{array}{c}.0001 \\
(.0002)\end{array}$ & $\begin{array}{l}-.0000 \\
(.0002)\end{array}$ & $\begin{array}{l}-.0001 \\
(.0002)\end{array}$ & $\begin{array}{l}-.0001 \\
(.0002)\end{array}$ \\
\hline Log population $_{\mathrm{t}-3}$ & $\begin{array}{l}.246^{\star *} \\
(.083)\end{array}$ & $\begin{array}{l}.247^{\star \star} \\
(.083)\end{array}$ & $\begin{array}{l}.180^{*} \\
(.075)\end{array}$ & $\begin{array}{l}.248^{\star *} \\
(.083)\end{array}$ & $\begin{array}{l}.259^{\star *} \\
(.085)\end{array}$ \\
\hline Log trade openness $\mathrm{t}_{-3}$ & $\begin{array}{l}.072^{* *} \\
(.012)\end{array}$ & $\begin{array}{l}.072^{\star *} \\
(.012)\end{array}$ & $\begin{array}{l}.075^{\star *} \\
(.013)\end{array}$ & $\begin{array}{l}.068^{* *} \\
(.013)\end{array}$ & $\begin{array}{l}.070^{\star *} \\
(.014)\end{array}$ \\
\hline Antitrust * democracy & & & & $\begin{array}{l}.0015^{+} \\
(.0008)\end{array}$ & \\
\hline $\begin{array}{l}\text { Antitrust * } \log \text { trade } \\
\text { openness }\end{array}$ & & & & $\begin{array}{l}.021^{*} \\
(.009)\end{array}$ & \\
\hline Observations & 3654 & 3653 & 3311 & 3654 & 2805 \\
\hline $\mathrm{R}^{2}$ & .07 & .07 & .08 & .07 & .06 \\
\hline
\end{tabular}

Notes: All specifications of the model are estimated using the first difference estimator.

$+p<\left..1\right|^{*} p<\left..05\right|^{* *} p<.01$

The situation is different for the effect of antitrust law on economic development. Table 4 shows that antitrust law clearly has a positive effect on economic development. Columns 1-3 again contain the results of the first difference estimator of the model with the binary measure of antitrust law. They differ with regard to the lag of the antitrust variable. The coefficient of the antitrust variable is highly significant in all three cases. Furthermore, the effect becomes stronger, the larger the lag is. An antitrust institution that exists for three years increases the GDP per capita by 2 percent; an antitrust institution that exists for ten years increases the GDP per capita by 2.6 percent. Column 5 shows the results if we substitute our binary measure by the variable measuring the effectiveness of the antitrust system using the antitrust law index. Here, antitrust law also has a significant positive effect on economic development. 
The model in column 4, finally, is a modification of the model with the binary antitrust measure as a three-year lag, which includes two interaction effects - one between antitrust law and trade openness and one between antitrust law and democracy. There is a significant positive interaction effect between antitrust law and trade openness. Therefore, the existence of an antitrust law and trade openness reinforce each other. The positive effect of trade openness on economic development is greater if a country simultaneously has an antitrust institution. At the same time, an antitrust institution is more effective with regard to economic development if a country is open to trade. Furthermore, there is a weakly significant positive interaction between antitrust and democracy. An antitrust institution is thus more effective in a democracy than in a non-democracy. This result should not be surprising if we consider democracy as a proxy for institutional effectiveness in general.

Finally, we analyze the effect of an antitrust institution on economic growth. If there is a positive effect on the level of economic development, there should also be a positive effect on economic growth. Table 5 shows the results of three fixed-effects OLS regressions of a three-year average of economic growth per capita on the binary antitrust measure. The existence of an antitrust regime has a strongly significant positive effect on economic growth. Again, we see that the antitrust regime is the more effective the longer it is in existence. Ten years after its introduction, the effect of an antitrust institution on economic growth per capita is more than $50 \%$ stronger than three years after its introduction.

Table 5: Effect of Antitrust Law on Growth per capita

\begin{tabular}{|c|c|c|c|}
\hline & (1) & (2) & (3) \\
\hline Antitrust $_{\mathrm{t}-3}$ & $\begin{array}{c}1.216^{* *} \\
(.369)\end{array}$ & & \\
\hline Antitrust $_{t-5}$ & & $\begin{array}{c}1.366^{* *} \\
(.368)\end{array}$ & \\
\hline Antitrust $_{\mathrm{t}-10}$ & & & $\begin{array}{c}1.982^{* *} \\
(.382)\end{array}$ \\
\hline Log GDP p. cap.t-3 & $\begin{array}{c}-4.945^{* *} \\
(.552)\end{array}$ & $\begin{array}{c}-4.990^{* *} \\
(.551)\end{array}$ & $\begin{array}{r}-5.388^{* *} \\
(.549)\end{array}$ \\
\hline Democracyt-3 & $\begin{array}{l}-.026 \\
(.027)\end{array}$ & $\begin{array}{l}-.025 \\
(.026)\end{array}$ & $\begin{array}{l}-.009 \\
(.027)\end{array}$ \\
\hline Resources $_{\mathrm{t}-3}$ & $\begin{array}{l}-.029^{*} \\
(.011)\end{array}$ & $\begin{array}{l}-.029^{*} \\
(.011)\end{array}$ & $\begin{array}{l}-.036^{*} \\
(.014)\end{array}$ \\
\hline Log population $\mathrm{t}_{\mathrm{t}-3}$ & $\begin{array}{l}-.384 \\
(.618)\end{array}$ & $\begin{array}{l}-.399 \\
(.613)\end{array}$ & $\begin{array}{l}-.343 \\
(.639\end{array}$ \\
\hline Log trade open $\mathrm{t}_{-3}$ & $\begin{array}{c}3.103^{* *} \\
(.542)\end{array}$ & $\begin{array}{c}3.098^{* *} \\
(.540)\end{array}$ & $\begin{array}{c}3.135^{\star *} \\
(.565)\end{array}$ \\
\hline Observations & 3955 & 3954 & 3602 \\
\hline
\end{tabular}

Notes: ${ }^{+} p<\left..1\right|^{*} p<\left..05\right|^{* *} p<.01$ 


\section{Discussion}

If we compare the effects of antitrust law, we find that antitrust institutions clearly have a positive effect on economic development. However, the influence on democracy seems to be weak at best. The only model that has a weakly significant effect is the one that includes a five-year lag. Does this mean that the ordoliberal thesis of the positive effect of antitrust law on democracy is wrong? Does economic concentration not pose dangers for democracy? These conclusions are not compulsive. Instead, we may think of three explanations for why the hypothesis of the negative effect of economic concentration on democracy may hold despite the results of our statistical analysis.

First, the results might simply be due to a measurement error. I have pointed out the difficulties of measuring the effectiveness of antitrust regimes. It may well be that in some cases the antitrust variable has the value one, although the antitrust regime of the respective country is totally ineffective. Consequently, some of the ones should have been zeros instead. This kind of measurement error should lead to an underestimation of the size of the coefficient. I have tried to mitigate this problem by also including a measure for the effectiveness of antitrust law by using the antitrust law index. The effect of the antitrust law index was even weaker than the one using only a binary measure. However, this measure is equally less than perfect as there may be a disparity between the formal scope of the antitrust law and its effectiveness in practice. Therefore, it cannot be totally excluded that the coefficients would have been slightly larger (and thus possibly statistically significant) if I had included a better measure for the effectiveness of the antitrust institutions into the model.

The other two reasons are of a more conceptual nature. It might be that the negative effects of economic concentration on the political system are of such a nature that they are not captured by the democracy score. Democratization does not necessarily lead to a vanishing of the influence of the economic elites on political decision-making. It only changes the form of the influence. Economic elites may influence politicians by the provision and selection of information, by campaign financing (Shapiro 2006: 108), or by certain decisions of their business policy that have an influence on the economic framework. If business elites have sufficient means to promote their interests even within democratic political systems, they may have fewer incentives to pursue a change of the system itself.

However, the biggest reason for why we do not observe a significant effect is probably the institutional structure of current antitrust laws. The existing antitrust laws want to guarantee competitive prices and thus aim at particular markets and not at the economy as a whole. As long as there is sufficient competition in a particular market, antitrust institutions are not concerned with the concentration of economic power. They try to prevent the existence of a dominant airline in the international civil aviation business, a dominant telephone company in the national communications business, or a dominant bakery in the local market for bread and pastries. However, antitrust law does not prevent business conglomerates with subsidiaries each in the civil aviation 
business, the telecommunications business and the bakery business from emerging - as long as there is sufficient competition in the individual markets.

Antitrust law is, in general, not designed to prevent economic concentration as such, but only a specific form of economic concentration (Amato 1997: 102-05). However, business conglomerates arguably have a far greater influence on the political system than companies dominating a particular market (Carstensen and Questal 1978: 863; Barnes 1989: 814). There is empirical evidence that conglomerate firms often control a considerable share of the national economy, which may range from twenty to more than fifty percent (Claessens et al. 2000; Kosenko 2007). Because of their size, they often have greater leverage and economic power. Furthermore, they may be able to mobilize support from a wider range of sources because they are likely to deal with a wider range of unions, suppliers and customers and thus have a wider network than firms concentrating on a particular market (Blake 1973: 591).

\section{Conclusion}

In the debate on the normative goals of antitrust law, there is not only disagreement about the appropriate goals that antitrust law is supposed to pursue, but also about the extent to which these different purposes are compatible with each other. ${ }^{17}$ The results of this study suggest that antitrust law, as it is currently designed, promotes economic development, but does little for democratization and the stability of democracy. The introduction of an antitrust institution has a positive effect on the level of GDP per capita and economic growth, while its effect on the democracy score of a country is statistically insignificant. However, this result is probably not due to the fact that preventing economic concentration is irrelevant for the quality of the political system. Rather, it may be a result of how antitrust regimes are preponderantly designed. If they focused more on economic concentration as such instead of dealing with particular markets, they might do a better job of promoting the case of democratic development in the world. 


\section{Appendix A: Data Sources}

\begin{tabular}{|c|c|c|}
\hline Variable & Description and Source & Web \\
\hline democracy & $\begin{array}{l}\text { polity2-variable of the Polity IV data set } \\
\text { (Marshall and Jaggers 2009) }\end{array}$ & $\begin{array}{l}\text { http://www.systemicpeace.org/ } \\
\text { polity/polity4.htm }\end{array}$ \\
\hline GPD per capita & $\begin{array}{l}\text { Real GPD per capita-variable (Chain se- } \\
\text { ries) of the Penn World Table } 6.3 \text { Database } \\
\text { (Heston et al. 2009) }\end{array}$ & http://pwt.econ.upenn.edu/ \\
\hline growth & $\begin{array}{l}\text { Growth rate of real GDP chain per capita of } \\
\text { the Penn World Table } 6.3 \text { Database (Hes- } \\
\text { ton et al. 2009) }\end{array}$ & http://pwt.econ.upenn.edu/ \\
\hline antitrust & $\begin{array}{l}\text { Years for the introduction of an antitrust } \\
\text { regime are taken from the Competition Law } \\
\text { Database of the World Bank and the websi- } \\
\text { te of the Global Competition Forum (for the } \\
\text { countries missing in the former database) }\end{array}$ & $\begin{array}{l}\text { http://go.worldbank.org/859XI9IVS0 } \\
\text { http://www.globalcompetitionforum.org/ }\end{array}$ \\
\hline ALI & $\begin{array}{l}\text { Scores for the antitrust law index are taken } \\
\text { from the Antitrust World Wiki webpage. The } \\
\text { ALI scores are divided by } 26 \text { (the maximum } \\
\text { a country scored on the index) in order to } \\
\text { make the effect comparable in size to the } \\
\text { binary antitrust measure }\end{array}$ & http://antitrustworldwiki.com/ \\
\hline $\begin{array}{l}\text { executive constrai- } \\
\text { nts }\end{array}$ & $\begin{array}{l}\text { exconst-variable of the Polity IV data set } \\
\text { (Marshall and Jaggers 2009) }\end{array}$ & $\begin{array}{l}\text { http://www.systemicpeace.org/ } \\
\text { polity/polity4.htm }\end{array}$ \\
\hline political competition & $\begin{array}{l}\text { polcomp-variable of the Polity IV data set } \\
\text { (Marshall and Jaggers 2009) }\end{array}$ & $\begin{array}{l}\text { http://www.systemicpeace.org/ } \\
\text { polity/polity4.htm }\end{array}$ \\
\hline trade openness & $\begin{array}{l}\text { Openness in current prices-variable of the } \\
\text { Penn World Table } 6.3 \text { Database (Heston et } \\
\text { al. 2009) }\end{array}$ & http://pwt.econ.upenn.edu/ \\
\hline resources & $\begin{array}{l}\text { Sum of the percentage of fuel and ores and } \\
\text { metals export of all merchandise exports. } \\
\text { Data is taken from the World Development } \\
\text { Indicators Databank for the World Bank }\end{array}$ & http://databank.worldbank.org/ \\
\hline $\begin{array}{l}\text { international en- } \\
\text { vironment }\end{array}$ & $\begin{array}{l}\text { Yearly average democracy score of all } \\
\text { countries }\end{array}$ & \\
\hline population & $\begin{array}{l}\text { Population-variable of the Penn World Tab- } \\
\text { le } 6.3 \text { Database (Heston et al. 2009) }\end{array}$ & http://pwt.econ.upenn.edu/ \\
\hline
\end{tabular}




\section{Appendix B: Antitrust Laws in the Data Base}

\begin{tabular}{|c|c|c|}
\hline Country & Yr/DS/D & Main characteristics of the antitrust regime \\
\hline \multirow{3}{*}{ Afghanistan } & - & \multirow{3}{*}{ No antitrust law to date } \\
\hline & - & \\
\hline & - & \\
\hline \multirow{3}{*}{ Albania } & 1995 & \multirow{3}{*}{$\begin{array}{l}\text { - prohibition of cartels and the abuse of market dominance } \\
\text { - procedure on merger control } \\
\text { - competition authority is a public, permanent collegial body }\end{array}$} \\
\hline & 0 & \\
\hline & $+7 \mathrm{yrs}$ & \\
\hline \multirow{3}{*}{ Algeria } & 1995 & \multirow{3}{*}{$\begin{array}{l}\text { - prohibition of cartels and the abuse of market dominance } \\
\text { - procedure on merger control } \\
\text { - public antitrust commission }\end{array}$} \\
\hline & -3 & \\
\hline & - & \\
\hline \multirow{3}{*}{ Angola } & - & \multirow{3}{*}{ No antitrust law to date } \\
\hline & - & \\
\hline & - & \\
\hline \multirow{3}{*}{ Argentina } & 1980 & \multirow{3}{*}{$\begin{array}{l}\text { - prohibition of cartels and the abuse of market dominance } \\
\text { - procedure on merger control } \\
\text { - tribunal for the defense of competition as independent public body }\end{array}$} \\
\hline & -9 & \\
\hline & $+3 \mathrm{yrs}$ & \\
\hline \multirow{3}{*}{ Armenia } & 2001 & \multirow{3}{*}{$\begin{array}{l}\text { - prohibition of cartels and the abuse of market dominance } \\
\text { - procedure on merger control } \\
\text { - independent public competition body }\end{array}$} \\
\hline & 5 & \\
\hline & - & \\
\hline \multirow{3}{*}{ Australia } & 1974 & \multirow{3}{*}{$\begin{array}{l}\text { - prohibition of cartels and the abuse of market dominance } \\
\text { - procedure on merger control } \\
\text { - competition and consumer commission }\end{array}$} \\
\hline & 10 & \\
\hline & -73 yrs & \\
\hline \multirow{3}{*}{ Austria } & 1988 & \multirow{3}{*}{$\begin{array}{l}\text { - prohibition of cartels and the abuse of market dominance } \\
\text { - procedure on merger control } \\
\text { - public authority and independent cartel court }\end{array}$} \\
\hline & 10 & \\
\hline & -42 yrs & \\
\hline \multirow{3}{*}{ Azerbaijan } & 1993 & \multirow{3}{*}{$\begin{array}{l}\text { - prohibition of cartels and the abuse of market dominance } \\
\text { - procedure on merger control } \\
\text { - antitrust authority is part of the ministry of economic development }\end{array}$} \\
\hline & -3 & \\
\hline & - & \\
\hline \multirow{3}{*}{ Bahrain } & - & \multirow{3}{*}{ No antitrust law to date } \\
\hline & - & \\
\hline & - & \\
\hline \multirow{3}{*}{ Bangladesh } & - & \multirow{3}{*}{ No antitrust law to date } \\
\hline & - & \\
\hline & - & \\
\hline \multirow{3}{*}{ Belarus } & 1992 & \multirow{3}{*}{$\begin{array}{l}\text { - prohibition of cartels and the abuse of market dominance } \\
\text { - procedure on merger control } \\
\text { - antimonopoly body as part of the Ministry of Entrepreneurship }\end{array}$} \\
\hline & 7 & \\
\hline & $-1 \mathrm{yr}$ & \\
\hline \multirow{3}{*}{ Belgium } & 1958 & \multirow{3}{*}{$\begin{array}{l}\text { - prohibition of cartels and the abuse of market dominance } \\
\text { - procedure on merger control } \\
\text { - independent competition authority }\end{array}$} \\
\hline & 10 & \\
\hline & -105 yrs & \\
\hline & - & \\
\hline Benin & - & No antitrust law to date \\
\hline & - & \\
\hline
\end{tabular}




\begin{tabular}{|c|c|c|}
\hline \multirow{3}{*}{ Bhutan } & - & \multirow{3}{*}{ No antitrust law to date } \\
\hline & - & \\
\hline & - & \\
\hline \multirow{3}{*}{ Bolivia } & - & \multirow{3}{*}{ No antitrust law to date } \\
\hline & - & \\
\hline & - & \\
\hline \multirow{3}{*}{ Botswana } & - & \multirow{3}{*}{ No antitrust law to date } \\
\hline & - & \\
\hline & - & \\
\hline \multirow{3}{*}{ Brazil } & 1994 & \multirow{3}{*}{$\begin{array}{l}\text { - prohibition of cartels and the abuse of market dominance } \\
\text { - procedure on merger control } \\
\text { - independent competition agency }\end{array}$} \\
\hline & 8 & \\
\hline & -9 yrs & \\
\hline \multirow{3}{*}{ Bulgaria } & 1998 & \multirow{3}{*}{$\begin{array}{l}\text { - prohibition of cartels and the abuse of market dominance } \\
\text { - procedure on merger control } \\
\text { - competition protection through independent state authority }\end{array}$} \\
\hline & 8 & \\
\hline & $-8 \mathrm{yrs}$ & \\
\hline \multirow{3}{*}{ Burkina Faso } & 1994 & \multirow{3}{*}{$\begin{array}{l}\text { - prohibition of cartels } \\
\text { - no merger control } \\
\text { - national competition commission as part of a ministry }\end{array}$} \\
\hline & -5 & \\
\hline & - & \\
\hline \multirow{3}{*}{ Burundi } & - & \multirow{3}{*}{ No antitrust law to date } \\
\hline & - & \\
\hline & - & \\
\hline \multirow{3}{*}{ Cambodia } & - & \multirow{3}{*}{ No antitrust law to date } \\
\hline & - & \\
\hline & - & \\
\hline \multirow{3}{*}{ Cameroon } & 1998 & \multirow{3}{*}{$\begin{array}{l}\text { - prohibition of cartels and the abuse of market dominance } \\
\text { - procedure on merger control } \\
\text { - public competition authority }\end{array}$} \\
\hline & -4 & \\
\hline & - & \\
\hline \multirow{3}{*}{ Canada } & 1889 & \multirow{3}{*}{$\begin{array}{l}\text { - prohibition of cartels and the abuse of market dominance } \\
\text { - procedure on merger control } \\
\text { - competition bureau as independent law enforcement agency }\end{array}$} \\
\hline & 9 & \\
\hline & $-1 \mathrm{yr}$ & \\
\hline \multirow{3}{*}{ Central African Rep. } & - & \multirow{3}{*}{ No antitrust law to date } \\
\hline & - & \\
\hline & - & \\
\hline \multirow{3}{*}{ Chad } & - & \multirow{3}{*}{ No antitrust law to date } \\
\hline & - & \\
\hline & - & \\
\hline \multirow{3}{*}{ Chile } & 1959 & - prohibition of cartels and the abuse of market dominance \\
\hline & 5 & - no merger control \\
\hline & $+5 \mathrm{yrs}$ & - competition authority under ministerial supervision \\
\hline & 2008 & \\
\hline China & -7 & No antitrust law before 2007 \\
\hline & - & \\
\hline & 1992 & - prohibition of cartels and the abuse of market dominance \\
\hline Colombia & 9 & - procedure on merger control \\
\hline & -35 yrs & - competition authority as part of a ministry \\
\hline
\end{tabular}




\begin{tabular}{|c|c|c|}
\hline \multirow{3}{*}{ Comoros } & - & \multirow{3}{*}{ No antitrust law to date } \\
\hline & - & \\
\hline & - & \\
\hline \multirow{3}{*}{ Congo Brazzaville } & - & \multirow{3}{*}{ No antitrust law to date } \\
\hline & - & \\
\hline & - & \\
\hline \multirow{3}{*}{ Congo Kinshasa } & - & \multirow{3}{*}{ No antitrust law to date } \\
\hline & - & \\
\hline & - & \\
\hline \multirow{3}{*}{ Costa Rica } & 1994 & \multirow{3}{*}{$\begin{array}{l}\text { - prohibition of cartels } \\
\text { - procedure on merger control } \\
\text { - competition authority as part of a ministry }\end{array}$} \\
\hline & 10 & \\
\hline & -119 yrs & \\
\hline \multirow{3}{*}{ Croatia } & 1995 & \multirow{3}{*}{$\begin{array}{l}\text { - prohibition of cartels and the abuse of market dominance } \\
\text { - procedure on merger control } \\
\text { - public antitrust authority }\end{array}$} \\
\hline & -5 & \\
\hline & $+5 \mathrm{yrs}$ & \\
\hline \multirow{3}{*}{ Cyprus } & 1989 & \multirow{3}{*}{$\begin{array}{l}\text { - prohibition of cartels and the abuse of market dominance } \\
\text { - procedure on merger control } \\
\text { - public antitrust authority }\end{array}$} \\
\hline & 10 & \\
\hline & $-21 \mathrm{yrs}$ & \\
\hline \multirow{3}{*}{ Czech Republic } & 1992 & \multirow{3}{*}{$\begin{array}{l}\text { - prohibition of cartels and the abuse of market dominance } \\
\text { - procedure on merger control } \\
\text { - public antitrust authority }\end{array}$} \\
\hline & 8 & \\
\hline & $-2 \mathrm{yrs}$ & \\
\hline \multirow{3}{*}{ Denmark } & 1972 & \multirow{3}{*}{$\begin{array}{l}\text { - prohibition of cartels and the abuse of market dominance } \\
\text { - procedure on merger control } \\
\text { - public antitrust authority }\end{array}$} \\
\hline & 10 & \\
\hline & -57 yrs & \\
\hline \multirow{3}{*}{ Djibouti } & - & \multirow{3}{*}{ No antitrust law to date } \\
\hline & - & \\
\hline & - & \\
\hline \multirow{3}{*}{ Dominican Republic } & - & \multirow{3}{*}{ No antitrust law to date } \\
\hline & - & \\
\hline & - & \\
\hline \multirow{3}{*}{ Ecuador } & - & \multirow{3}{*}{ No antitrust law to date } \\
\hline & - & \\
\hline & - & \\
\hline \multirow{3}{*}{ Egypt } & 2005 & \multirow{3}{*}{$\begin{array}{l}\text { - prohibition of cartels and the abuse of market dominance } \\
\text { - only notification obligation in merger cases } \\
\text { - independent antitrust authority }\end{array}$} \\
\hline & -3 & \\
\hline & - & \\
\hline \multirow{3}{*}{ El Salvador } & - & \\
\hline & - & No antitrust law to date \\
\hline & - & \\
\hline & - & \\
\hline Equatorial Guinea & - & No antitrust law to date \\
\hline & - & \\
\hline & - & \\
\hline Eritrea & - & No antitrust law to date \\
\hline & - & \\
\hline
\end{tabular}




\begin{tabular}{|c|c|c|}
\hline \multirow{3}{*}{ Estonia } & 1993 & \multirow{3}{*}{$\begin{array}{l}\text { - prohibition of cartels and the abuse of market dominance } \\
\text { - procedure on merger control } \\
\text { - public antitrust authority under ministerial control }\end{array}$} \\
\hline & 6 & \\
\hline & $-2 \mathrm{yrs}$ & \\
\hline \multirow{3}{*}{ Ethiopia } & - & \multirow{3}{*}{ No antitrust law to date } \\
\hline & - & \\
\hline & - & \\
\hline \multirow{3}{*}{ Fiji } & 1998 & \multirow{3}{*}{$\begin{array}{l}\text { - prohibition of cartels and the abuse of market dominance } \\
\text { - procedure on merger control } \\
\text { - independent competition authority }\end{array}$} \\
\hline & 5 & \\
\hline & $+1 \mathrm{yr}$ & \\
\hline \multirow{3}{*}{ Finland } & 1988 & \multirow{3}{*}{$\begin{array}{l}\text { - prohibition of cartels and the abuse of market dominance } \\
\text { - procedure on merger control } \\
\text { - independent competition authority }\end{array}$} \\
\hline & 10 & \\
\hline & -44 yrs & \\
\hline \multirow{3}{*}{ France } & 1953 & \multirow{3}{*}{$\begin{array}{l}\text { - prohibition of cartels and the abuse of market dominance } \\
\text { - procedure on merger control } \\
\text { - interplay of independent and ministerial competition authorities }\end{array}$} \\
\hline & 10 & \\
\hline & $-7 \mathrm{yrs}$ & \\
\hline \multirow{3}{*}{ Gabon } & - & \multirow{3}{*}{ No antitrust law to date } \\
\hline & - & \\
\hline & - & \\
\hline \multirow{3}{*}{ Gambia } & - & \multirow{3}{*}{ No antitrust law to date } \\
\hline & - & \\
\hline & - & \\
\hline \multirow{3}{*}{ Georgia } & 1996 & \multirow{3}{*}{$\begin{array}{l}\text { Georgia basically abolished its antitrust law in } 2005 \text {. The new } 2005 \text { act } \\
\text { covers neither anticompetitive agreements nor the abuse of dominant } \\
\text { market positions or the control of mergers }\end{array}$} \\
\hline & 5 & \\
\hline & $+8 \mathrm{yrs}$ & \\
\hline \multirow{3}{*}{ Germany } & 1958 & \multirow{3}{*}{$\begin{array}{l}\text { - prohibition of cartels and the abuse of market dominance } \\
\text { - procedure on merger control } \\
\text { - independent competition authority }\end{array}$} \\
\hline & 10 & \\
\hline & -9 yrs & \\
\hline \multirow{3}{*}{ Ghana } & - & \multirow{3}{*}{ No antitrust law to date } \\
\hline & - & \\
\hline & - & \\
\hline \multirow{3}{*}{ Greece } & 1977 & \multirow{3}{*}{$\begin{array}{l}\text { - prohibition of cartels and the abuse of market dominance } \\
\text { - procedure on merger control } \\
\text { - public competition authority }\end{array}$} \\
\hline & 8 & \\
\hline & -2 yrs & \\
\hline \multirow{3}{*}{ Guatemala } & - & \multirow{3}{*}{ No antitrust law to date } \\
\hline & - & \\
\hline & - & \\
\hline \multirow{3}{*}{ Guinea } & - & \\
\hline & - & No antitrust law to date \\
\hline & - & \\
\hline & - & \\
\hline Guinea-Bissau & - & No antitrust law to date \\
\hline & - & \\
\hline & - & \\
\hline Guyana & - & No antitrust law to date \\
\hline & - & \\
\hline
\end{tabular}




\begin{tabular}{|c|c|c|}
\hline \multirow{3}{*}{ Haiti } & - & \multirow{3}{*}{ No antitrust law to date } \\
\hline & - & \\
\hline & - & \\
\hline \multirow{3}{*}{ Honduras } & 2006 & \multirow{3}{*}{$\begin{array}{l}\text { - prohibition of cartels } \\
\text { - procedure on merger control } \\
\text { - independent competition authority }\end{array}$} \\
\hline & 7 & \\
\hline & -17 yrs & \\
\hline \multirow{3}{*}{ Hungary } & 1997 & \multirow{3}{*}{$\begin{array}{l}\text { - prohibition of cartels and the abuse of market dominance } \\
\text { - procedure on merger control } \\
\text { - independent competition authority }\end{array}$} \\
\hline & 10 & \\
\hline & $-7 \mathrm{yrs}$ & \\
\hline \multirow{3}{*}{ India } & 1969 & \multirow{3}{*}{$\begin{array}{l}\text { - prohibition of cartels and the abuse of market dominance } \\
\text { - procedure on merger control } \\
\text { - competition authority is quasi-judicial body }\end{array}$} \\
\hline & 9 & \\
\hline & -19 yrs & \\
\hline \multirow{3}{*}{ Indonesia } & 1999 & \multirow{3}{*}{$\begin{array}{l}\text { - prohibition of cartels and the abuse of market dominance } \\
\text { - procedure on merger control } \\
\text { - independent competition authority }\end{array}$} \\
\hline & 6 & \\
\hline & 0 yrs & \\
\hline \multirow{3}{*}{ Iran } & - & \multirow{3}{*}{ No antitrust law to date } \\
\hline & - & \\
\hline & - & \\
\hline \multirow{3}{*}{ Iraq } & - & \multirow{3}{*}{ No antitrust law to date } \\
\hline & - & \\
\hline & - & \\
\hline \multirow{3}{*}{ Ireland } & 1973 & \multirow{3}{*}{$\begin{array}{l}\text { - prohibition of cartels and the abuse of market dominance } \\
\text { - procedure on merger control } \\
\text { - independent competition authority }\end{array}$} \\
\hline & 10 & \\
\hline & -52 yrs & \\
\hline \multirow{3}{*}{ Israel } & 1988 & \multirow{3}{*}{$\begin{array}{l}\text { - prohibition of cartels and the abuse of market dominance } \\
\text { - procedure on merger control } \\
\text { - antitrust authority as part of a ministry }\end{array}$} \\
\hline & 9 & \\
\hline & -40 yrs & \\
\hline \multirow{3}{*}{ Italy } & 1958 & \multirow{3}{*}{$\begin{array}{l}\text { - prohibition of cartels and the abuse of market dominance } \\
\text { - procedure on merger control } \\
\text { - independent competition authority }\end{array}$} \\
\hline & 10 & \\
\hline & $-10 \mathrm{yrs}$ & \\
\hline \multirow{3}{*}{ Ivory Coast } & 1991 & \multirow{3}{*}{$\begin{array}{l}\text { - prohibition of the abuse of market dominance and restrictive trade } \\
\text { practices } \\
\text { - an antitrust authority exists, but does not seem to be very active }\end{array}$} \\
\hline & -7 & \\
\hline & - & \\
\hline \multirow{3}{*}{ Jamaica } & 1993 & \multirow{3}{*}{$\begin{array}{l}\text { - prohibition of cartels and the abuse of market dominance } \\
\text { - no merger control } \\
\text { - public competition authority under ministerial supervision }\end{array}$} \\
\hline & 9 & \\
\hline & - & \\
\hline \multirow{3}{*}{ Japan } & 1947 & - prohibition of cartels \\
\hline & . & - procedure on merger control \\
\hline & $+5 \mathrm{yrs}$ & - competition authority is attached to the office of the prime minister \\
\hline & 2004 & - prohibition of cartels and the abuse of market dominance \\
\hline Jordan & -2 & - procedure on merger control \\
\hline & - & - competition authority as part of a ministry \\
\hline & 2001 & - prohibition of cartels and the abuse of market dominance \\
\hline Kazakhstan & -4 & - procedure on merger control \\
\hline & - & - public competition authority \\
\hline
\end{tabular}




\begin{tabular}{|c|c|c|}
\hline \multirow{3}{*}{ Kenya } & 1988 & \multirow{3}{*}{$\begin{array}{l}\text { - prohibition of cartels } \\
\text { - procedure on merger control } \\
\text { - competition authority as part of a ministry }\end{array}$} \\
\hline & -7 & \\
\hline & +14 yrs & \\
\hline \multirow{3}{*}{ Korea South } & 1980 & \multirow{3}{*}{$\begin{array}{l}\text { - prohibition of cartels and the abuse of market dominance } \\
\text { - procedure on merger control } \\
\text { - public competition authority }\end{array}$} \\
\hline & -8 & \\
\hline & +8 yrs & \\
\hline \multirow{3}{*}{ Kuwait } & - & \multirow{3}{*}{ No antitrust law to date } \\
\hline & - & \\
\hline & - & \\
\hline \multirow{3}{*}{ Kyrgyzstan } & 1994 & \multirow{3}{*}{$\begin{array}{l}\text { - prohibition of cartels and the abuse of market dominance } \\
\text { - procedure on merger control } \\
\text { - public competition authority }\end{array}$} \\
\hline & -3 & \\
\hline & - & \\
\hline \multirow{3}{*}{ Laos } & 2004 & \multirow{3}{*}{$\begin{array}{l}\text { - prohibition of cartels } \\
\text { - provisions on mergers } \\
\text { - competition authority as department of a ministry }\end{array}$} \\
\hline & -7 & \\
\hline & - & \\
\hline \multirow{3}{*}{ Latvia } & 1998 & \multirow{3}{*}{$\begin{array}{l}\text { - prohibition of cartels and the abuse of market dominance } \\
\text { - procedure on merger control } \\
\text { - independent competition authority }\end{array}$} \\
\hline & 8 & \\
\hline & $-7 \mathrm{yrs}$ & \\
\hline \multirow{3}{*}{ Lebanon } & - & \multirow{3}{*}{ No antitrust law to date } \\
\hline & - & \\
\hline & - & \\
\hline \multirow{3}{*}{ Lesotho } & - & \multirow{3}{*}{ No antitrust law to date } \\
\hline & - & \\
\hline & - & \\
\hline \multirow{3}{*}{ Liberia } & - & \multirow{3}{*}{ No antitrust law to date } \\
\hline & - & \\
\hline & - & \\
\hline \multirow{3}{*}{ Libya } & - & \multirow{3}{*}{ No antitrust law to date } \\
\hline & - & \\
\hline & - & \\
\hline \multirow{3}{*}{ Lithuania } & 1999 & \multirow{3}{*}{$\begin{array}{l}\text { - prohibition of cartels and the abuse of market dominance } \\
\text { - procedure on merger control } \\
\text { - independent competition authority }\end{array}$} \\
\hline & 10 & \\
\hline & $-8 \mathrm{yrs}$ & \\
\hline \multirow{3}{*}{ Macedonia } & 2000 & \multirow{3}{*}{$\begin{array}{l}\text { - prohibition of cartels and the abuse of market dominance } \\
\text { - procedure on merger control } \\
\text { - independent competition authority }\end{array}$} \\
\hline & 6 & \\
\hline & -9 yrs & \\
\hline \multirow{3}{*}{ Madagascar } & - & \\
\hline & - & No antitrust law to date \\
\hline & - & \\
\hline & 1998 & - prohibition of cartels and the abuse of market dominance \\
\hline Malawi & 6 & - procedure on merger control \\
\hline & -4 yrs & - independent competition authority \\
\hline & - & \\
\hline Malaysia & - & No antitrust law to date \\
\hline & - & \\
\hline
\end{tabular}




\begin{tabular}{|c|c|c|}
\hline \multirow{3}{*}{ Mali } & - & \multirow{3}{*}{ No antitrust law to date } \\
\hline & - & \\
\hline & - & \\
\hline \multirow{3}{*}{ Mauritania } & - & \multirow{3}{*}{ No antitrust law to date } \\
\hline & - & \\
\hline & - & \\
\hline \multirow{3}{*}{ Mauritius } & 2003 & \multirow{3}{*}{$\begin{array}{l}\text { - prohibition of cartels and the abuse of market dominance } \\
\text { - no merger control } \\
\text { - public competition authority under ministerial supervision }\end{array}$} \\
\hline & 10 & \\
\hline & -35 yrs & \\
\hline \multirow{3}{*}{ Mexico } & 1992 & \multirow{3}{*}{$\begin{array}{l}\text { - prohibition of cartels and the abuse of market dominance } \\
\text { - procedure on merger control } \\
\text { - competition authority as part of a ministry }\end{array}$} \\
\hline & 0 & \\
\hline & $+5 \mathrm{yrs}$ & \\
\hline \multirow{3}{*}{ Moldova } & 1992 & \multirow{3}{*}{$\begin{array}{l}\text { - prohibition of cartels and the abuse of market dominance } \\
\text { - procedure on merger control } \\
\text { - public competition authority }\end{array}$} \\
\hline & 5 & \\
\hline & $+1 \mathrm{yr}$ & \\
\hline \multirow{3}{*}{ Mongolia } & 1993 & \multirow{3}{*}{$\begin{array}{l}\text { - prohibition of cartels and the abuse of market dominance } \\
\text { - no merger control } \\
\text { - implementation of antitrust law by courts }\end{array}$} \\
\hline & 9 & \\
\hline & $-1 \mathrm{yr}$ & \\
\hline \multirow{3}{*}{ Morocco } & 2001 & \multirow{3}{*}{$\begin{array}{l}\text { - prohibition of cartels and the abuse of market dominance } \\
\text { - procedure on merger control } \\
\text { - public competition authority }\end{array}$} \\
\hline & -6 & \\
\hline & - & \\
\hline \multirow{3}{*}{ Mozambique } & - & \multirow{3}{*}{ No antitrust law to date } \\
\hline & - & \\
\hline & - & \\
\hline \multirow{3}{*}{ Namibia } & 2003 & \multirow{3}{*}{$\begin{array}{l}\text { - prohibition of cartels and the abuse of market dominance } \\
\text { - procedure on merger control } \\
\text { - public competition authority under ministerial supervision }\end{array}$} \\
\hline & 6 & \\
\hline & -13 yrs & \\
\hline \multirow{3}{*}{ Nepal } & - & \multirow{3}{*}{ No antitrust law to date } \\
\hline & - & \\
\hline & - & \\
\hline \multirow{3}{*}{ Netherlands } & 1956 & \multirow{3}{*}{$\begin{array}{l}\text { - prohibition of cartels and the abuse of market dominance } \\
\text { - procedure on merger control } \\
\text { - independent competition authority }\end{array}$} \\
\hline & 10 & \\
\hline & -39 yrs & \\
\hline \multirow{3}{*}{ New Zealand } & 1986 & \multirow{3}{*}{$\begin{array}{l}\text { - prohibition of cartels and the abuse of market dominance } \\
\text { - procedure on merger control } \\
\text { - independent competition authority }\end{array}$} \\
\hline & 10 & \\
\hline & -109 yrs & \\
\hline \multirow{3}{*}{ Nicaragua } & 2006 & - prohibition of cartels and the abuse of market dominance \\
\hline & 8 & - procedure on merger control \\
\hline & -16 yrs & - independent competition authority \\
\hline & - & \\
\hline Niger & - & No antitrust law to date \\
\hline & - & \\
\hline & - & \\
\hline Nigeria & - & No antitrust law to date \\
\hline & - & \\
\hline
\end{tabular}




\begin{tabular}{|c|c|c|}
\hline \multirow{3}{*}{ Norway } & 1993 & \multirow{3}{*}{$\begin{array}{l}\text { - prohibition of cartels and the abuse of market dominance } \\
\text { - procedure on merger control } \\
\text { - public competition authority under ministerial supervision }\end{array}$} \\
\hline & 10 & \\
\hline & -95 yrs & \\
\hline \multirow{3}{*}{ Oman } & - & \multirow{3}{*}{ No antitrust law to date } \\
\hline & - & \\
\hline & - & \\
\hline \multirow{3}{*}{ Pakistan } & 1971 & \multirow{3}{*}{$\begin{array}{l}\text { - prohibition of cartels and the abuse of market dominance } \\
\text { - procedure on merger control } \\
\text { - independent competition authority }\end{array}$} \\
\hline & 0 & \\
\hline & +3 yrs & \\
\hline \multirow{3}{*}{ Panama } & 1996 & \multirow{3}{*}{$\begin{array}{l}\text { - prohibition of cartels and the abuse of market dominance } \\
\text { - procedure on merger control } \\
\text { - independent competition authority }\end{array}$} \\
\hline & 9 & \\
\hline & -7 yrs & \\
\hline \multirow{3}{*}{ Papua New Guinea } & 1996 & \multirow{3}{*}{$\begin{array}{l}\text { - prohibition of cartels and the abuse of market dominance } \\
\text { - procedure on merger control } \\
\text { - independent competition authority }\end{array}$} \\
\hline & 4 & \\
\hline & - & \\
\hline \multirow{3}{*}{ Paraguay } & - & \multirow{3}{*}{ No antitrust law to date } \\
\hline & - & \\
\hline & - & \\
\hline \multirow{3}{*}{ Peru } & 1991 & \multirow{3}{*}{$\begin{array}{l}\text { - prohibition of cartels and the abuse of market dominance } \\
\text { - no merger control } \\
\text { - independent competition authority }\end{array}$} \\
\hline & 8 & \\
\hline & -11 yrs & \\
\hline \multirow{3}{*}{ Philippines } & - & \multirow{3}{*}{ No antitrust law to date } \\
\hline & - & \\
\hline & - & \\
\hline \multirow{3}{*}{ Poland } & 1990 & \multirow{3}{*}{$\begin{array}{l}\text { - prohibition of cartels and the abuse of market dominance } \\
\text { - procedure on merger control } \\
\text { - public competition authority under supervision of the prime minister }\end{array}$} \\
\hline & 5 & \\
\hline & $+1 \mathrm{yr}$ & \\
\hline \multirow{3}{*}{ Portugal } & 1986 & \multirow{3}{*}{$\begin{array}{l}\text { - prohibition of cartels and the abuse of market dominance } \\
\text { - procedure on merger control } \\
\text { - public competition authority }\end{array}$} \\
\hline & 10 & \\
\hline & -10 yrs & \\
\hline \multirow{3}{*}{ Qatar } & - & \multirow{3}{*}{ No antitrust law to date } \\
\hline & - & \\
\hline & - & \\
\hline \multirow{3}{*}{ Romania } & 1997 & \multirow{3}{*}{$\begin{array}{l}\text { - prohibition of cartels and the abuse of market dominance } \\
\text { - procedure on merger control } \\
\text { - independent competition authority }\end{array}$} \\
\hline & 8 & \\
\hline & $-1 \mathrm{yr}$ & \\
\hline \multirow{3}{*}{ Russia } & 1992 & - prohibition of cartels and the abuse of market dominance \\
\hline & 5 & - procedure on merger control \\
\hline & +8 yrs & - public competition authority \\
\hline & - & \\
\hline Rwanda & - & No antitrust law to date \\
\hline & - & \\
\hline & 2004 & - prohibition of cartels and the abuse of market dominance \\
\hline Saudi Arabia & -10 & - procedure on merger control \\
\hline & - & - ministerial committee as competition authority \\
\hline
\end{tabular}




\begin{tabular}{|c|c|c|}
\hline \multirow{3}{*}{ Senegal } & 1994 & \multirow{3}{*}{$\begin{array}{l}\text { - prohibition of cartels } \\
\text { - no merger control } \\
\text { - public competition authority }\end{array}$} \\
\hline & -1 & \\
\hline & +6 yrs & \\
\hline \multirow{3}{*}{ Serbia } & 1999 & \multirow{3}{*}{$\begin{array}{l}\text { - prohibition of cartels and the abuse of market dominance } \\
\text { - procedure on merger control } \\
\text { - public competition authority }\end{array}$} \\
\hline & -6 & \\
\hline & $+1 \mathrm{yr}$ & \\
\hline \multirow{3}{*}{ Sierra Leone } & - & \multirow{3}{*}{ No antitrust law to date } \\
\hline & - & \\
\hline & - & \\
\hline \multirow{3}{*}{ Singapore } & 2004 & \multirow{3}{*}{$\begin{array}{l}\text { - prohibition of cartels and the abuse of market dominance } \\
\text { - procedure on merger control } \\
\text { - competition authority under ministerial supervision }\end{array}$} \\
\hline & -2 & \\
\hline & - & \\
\hline \multirow{3}{*}{ Slovak Republic } & 1993 & \multirow{3}{*}{$\begin{array}{l}\text { - prohibition of cartels and the abuse of market dominance } \\
\text { - procedure on merger control } \\
\text { - independent competition authority }\end{array}$} \\
\hline & 7 & \\
\hline & 0 yrs & \\
\hline \multirow{3}{*}{ Slovenia } & 1999 & \multirow{3}{*}{$\begin{array}{l}\text { - prohibition of cartels and the abuse of market dominance } \\
\text { - procedure on merger control } \\
\text { - independent competition authority }\end{array}$} \\
\hline & 10 & \\
\hline & $-8 \mathrm{yrs}$ & \\
\hline \multirow{3}{*}{ Solomon Islands } & - & \multirow{3}{*}{ No antitrust law to date } \\
\hline & - & \\
\hline & - & \\
\hline \multirow{3}{*}{ Somalia } & - & \multirow{3}{*}{ No antitrust law to date } \\
\hline & - & \\
\hline & - & \\
\hline \multirow{3}{*}{ South Africa } & 1979 & \multirow{3}{*}{$\begin{array}{l}\text { - prohibition of cartels and the abuse of market dominance } \\
\text { - procedure on merger control } \\
\text { - independent competition authority }\end{array}$} \\
\hline & 4 & \\
\hline & +13 yrs & \\
\hline \multirow{3}{*}{ Spain } & 1986 & \multirow{3}{*}{$\begin{array}{l}\text { - prohibition of cartels and the abuse of market dominance } \\
\text { - procedure on merger control } \\
\text { - independent competition authority }\end{array}$} \\
\hline & 10 & \\
\hline & $-8 \mathrm{yrs}$ & \\
\hline \multirow{3}{*}{ Sri Lanka } & 1987 & \multirow{3}{*}{$\begin{array}{l}\text { - prohibition of abuse of market dominance } \\
\text { - merger control } \\
\text { - competition authority appointed by minister }\end{array}$} \\
\hline & 5 & \\
\hline & +14 yrs & \\
\hline \multirow{3}{*}{ Sudan } & - & \multirow{3}{*}{ No antitrust law to date } \\
\hline & - & \\
\hline & - & \\
\hline \multirow{3}{*}{ Swaziland } & - & \\
\hline & - & No antitrust law to date \\
\hline & - & \\
\hline & 1953 & - prohibition of cartels and the abuse of market dominance \\
\hline Sweden & 10 & - procedure on merger control \\
\hline & -36 yrs & - independent competition authority \\
\hline & 1985 & - prohibition of cartels and the abuse of market dominance \\
\hline Switzerland & 10 & - procedure on merger control \\
\hline & $-137 \mathrm{yrs}$ & - independent competition authority \\
\hline
\end{tabular}




\begin{tabular}{|c|c|c|}
\hline \multirow{3}{*}{ Syria } & - & \multirow{3}{*}{ No antitrust law to date } \\
\hline & - & \\
\hline & - & \\
\hline \multirow{3}{*}{ Tajikistan } & 2000 & \multirow{3}{*}{$\begin{array}{l}\text { - prohibition of cartels and the abuse of market dominance } \\
\text { - procedure on merger control } \\
\text { - public competition authority }\end{array}$} \\
\hline & -1 & \\
\hline & - & \\
\hline \multirow{3}{*}{ Tanzania } & 1994 & \multirow{3}{*}{$\begin{array}{l}\text { - prohibition of cartels and the abuse of market dominance } \\
\text { - procedure on merger control } \\
\text { - independent competition authority }\end{array}$} \\
\hline & -5 & \\
\hline & - & \\
\hline \multirow{3}{*}{ Thailand } & 1999 & \multirow{3}{*}{$\begin{array}{l}\text { - prohibition of cartels and the abuse of market dominance } \\
\text { - procedure on merger control } \\
\text { - competition authority as part of a ministry }\end{array}$} \\
\hline & 9 & \\
\hline & $-7 \mathrm{yrs}$ & \\
\hline \multirow{3}{*}{ Togo } & - & \multirow{3}{*}{ No antitrust law to date } \\
\hline & - & \\
\hline & - & \\
\hline \multirow{3}{*}{ Trinidad } & - & \multirow{3}{*}{ No antitrust law to date } \\
\hline & - & \\
\hline & - & \\
\hline \multirow{3}{*}{ Tunisia } & 1991 & \multirow{3}{*}{$\begin{array}{l}\text { - prohibition of cartels and the abuse of market dominance } \\
\text { - procedure on merger control } \\
\text { - public competition authority }\end{array}$} \\
\hline & -5 & \\
\hline & - & \\
\hline \multirow{3}{*}{ Turkey } & 1997 & \multirow{3}{*}{$\begin{array}{l}\text { - prohibition of cartels and the abuse of market dominance } \\
\text { - procedure on merger control } \\
\text { - public competition authority }\end{array}$} \\
\hline & 7 & \\
\hline & -14 yrs & \\
\hline \multirow{3}{*}{ Turkmenistan } & - & \multirow{3}{*}{ No antitrust law to date } \\
\hline & - & \\
\hline & - & \\
\hline \multirow{3}{*}{ United Arab Emirates } & - & \multirow{3}{*}{ No antitrust law to date } \\
\hline & - & \\
\hline & - & \\
\hline \multirow{3}{*}{ Uganda } & - & \multirow{3}{*}{ No antitrust law to date } \\
\hline & - & \\
\hline & - & \\
\hline \multirow{3}{*}{ Ukraine } & 2001 & \multirow{3}{*}{$\begin{array}{l}\text { - prohibition of cartels and the abuse of market dominance } \\
\text { - procedure on merger control } \\
\text { - public competition authority }\end{array}$} \\
\hline & 6 & \\
\hline & $-7 \mathrm{yrs}$ & \\
\hline \multirow{3}{*}{ United Kingdom } & 1948 & - prohibition of cartels and the abuse of market dominance \\
\hline & 10 & - procedure on merger control \\
\hline & -68 yrs & - independent competition authority \\
\hline & 1891 & - prohibition of cartels and the abuse of market dominance \\
\hline United States & 10 & - procedure on merger control \\
\hline & -82 yrs & - independent competition authority \\
\hline & 2000 & - prohibition of cartels and the abuse of market dominance \\
\hline Uruguay & 10 & - merger notification requirement \\
\hline & -15 yrs & - independent competition authority \\
\hline
\end{tabular}




\begin{tabular}{|c|c|c|}
\hline \multirow{3}{*}{ Uzbekistan } & 1996 & \multirow{3}{*}{$\begin{array}{l}\text { - prohibition of cartels and the abuse of market dominance } \\
\text { - procedure on merger control } \\
\text { - public competition authority }\end{array}$} \\
\hline & -9 & \\
\hline & - & \\
\hline \multirow{3}{*}{ Venezuela } & 1992 & \multirow{3}{*}{$\begin{array}{l}\text { - prohibition of cartels and the abuse of market dominance } \\
\text { - procedure on merger control } \\
\text { - public competition authority }\end{array}$} \\
\hline & 8 & \\
\hline & -34 yrs & \\
\hline \multirow{3}{*}{ Vietnam } & 2005 & \multirow{3}{*}{$\begin{array}{l}\text { - prohibition of cartels and the abuse of market dominance } \\
\text { - procedure on merger control } \\
\text { - competition authority as part of a ministry }\end{array}$} \\
\hline & -7 & \\
\hline & - & \\
\hline \multirow{3}{*}{ Zambia } & 1994 & \multirow{3}{*}{$\begin{array}{l}\text { - prohibition of cartels and the abuse of market dominance } \\
\text { - procedure on merger control } \\
\text { - competition authority as part of a ministry }\end{array}$} \\
\hline & 6 & \\
\hline & -3 yrs & \\
\hline \multirow{3}{*}{ Zimbabwe } & 1996 & \multirow{3}{*}{$\begin{array}{l}\text { - prohibition of cartels } \\
\text { - procedure on merger control } \\
\text { - competition authority under ministerial supervision }\end{array}$} \\
\hline & -6 & \\
\hline & - & \\
\hline
\end{tabular}

Notes: The first row of the second column of each state indicates when the antitrust regime was introduced; the second row indicates the democracy score in that year; and the third row indicates when the country experienced a transition to democracy (polity2-score of more than 5). If the country was democratic when it introduced the antitrust law, the number is negative, i.e. the transition was in the past if the country was not democratic, the number is either positive, i.e. the transition followed subsequently, or is missing in case there hasn't been a transition to date. The characteristics of the antitrust law refer to the state of the law in 2007, the last year of our observations. If the year of adopting the antitrust law and the year of entering into force or even the year when the enforcement started differ, this table (and the data of our analysis) refers to the entering into force and the start of the enforcement. 


\section{Appendix C: Graphs and Figures}

Figure 1: The Introduction of Antitrust Regimes

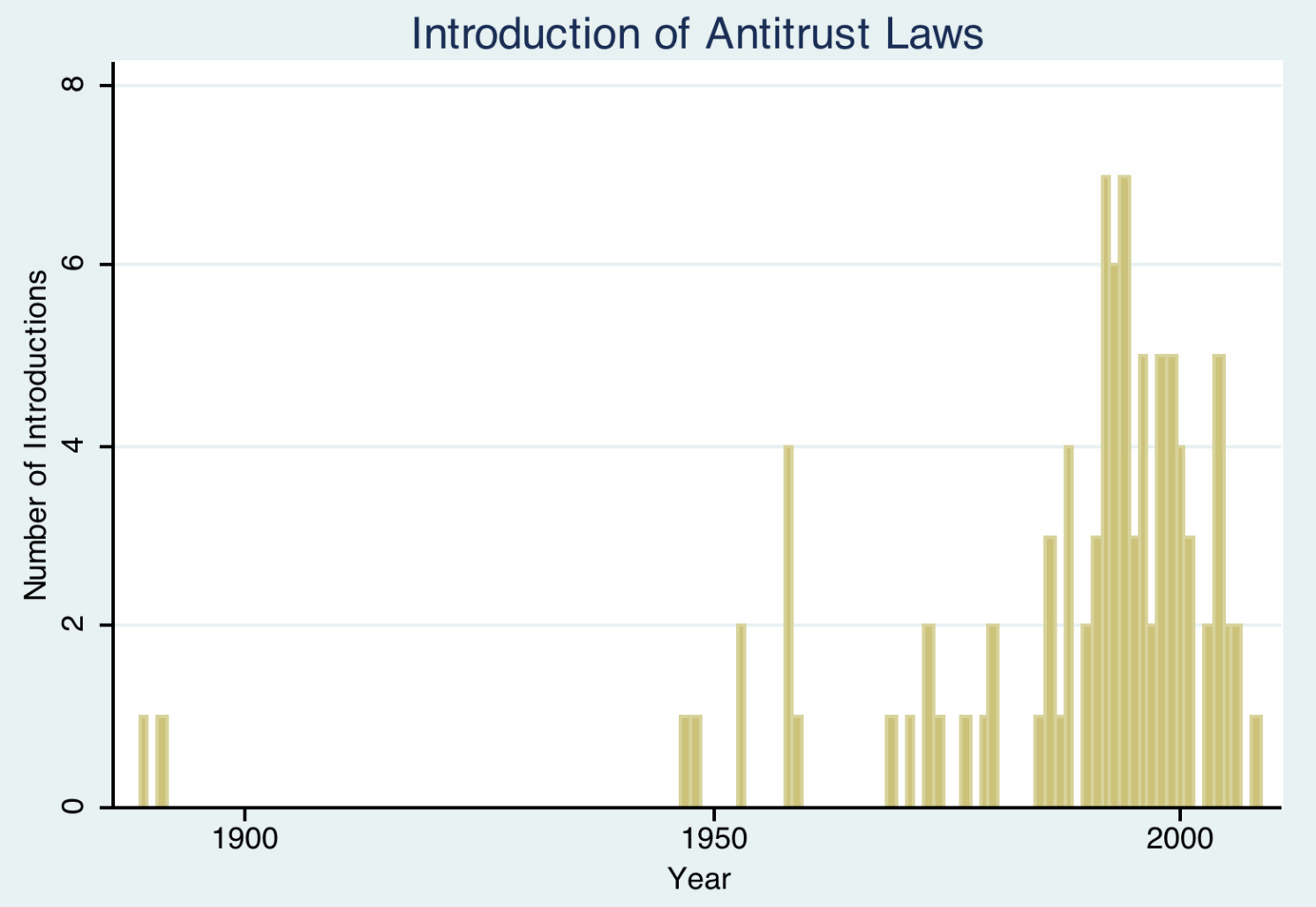


Figure 2: The Introduction of an Antitrust Law in South Korea

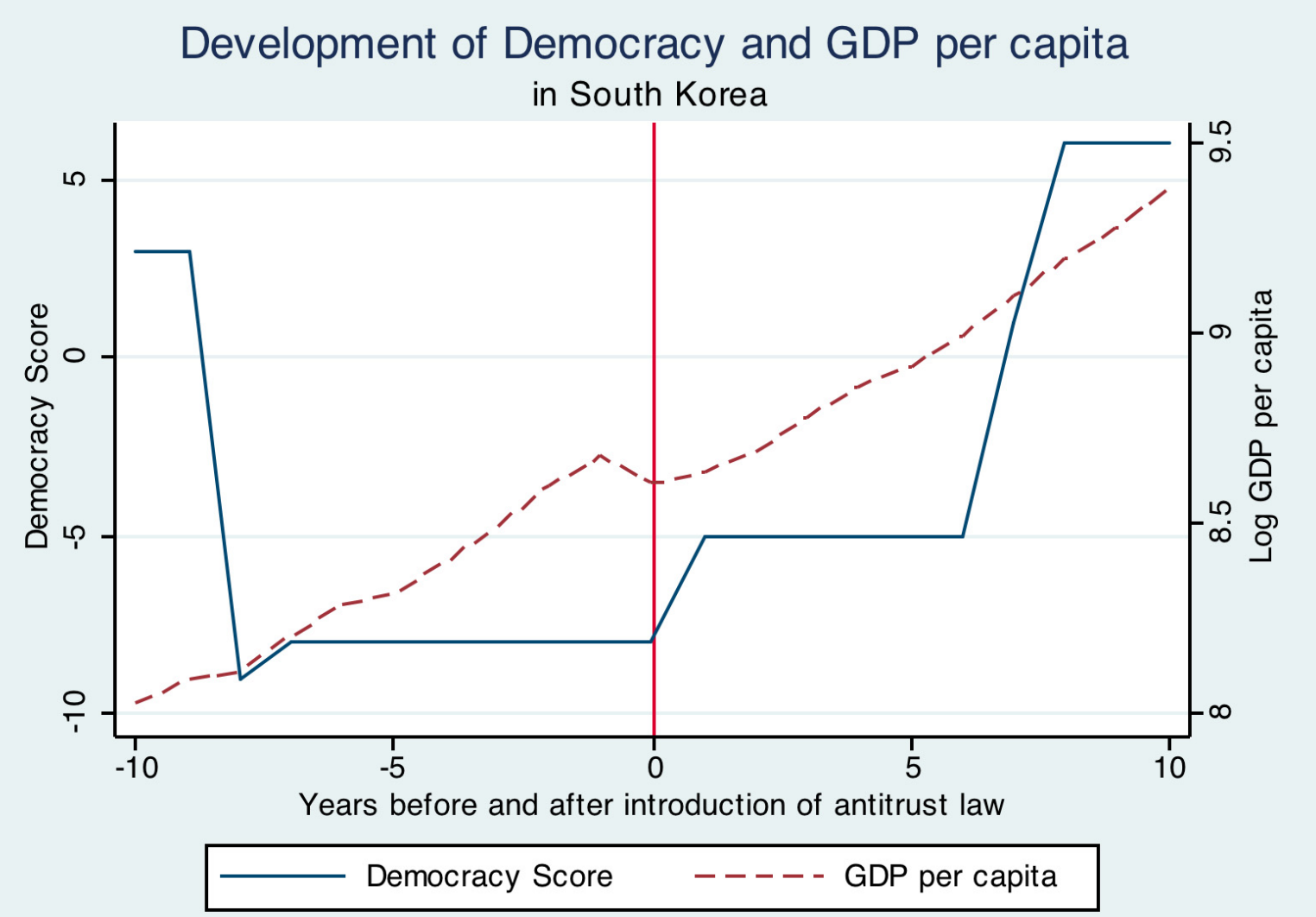


Figure 3: The Introduction of an Antitrust Law in Senegal

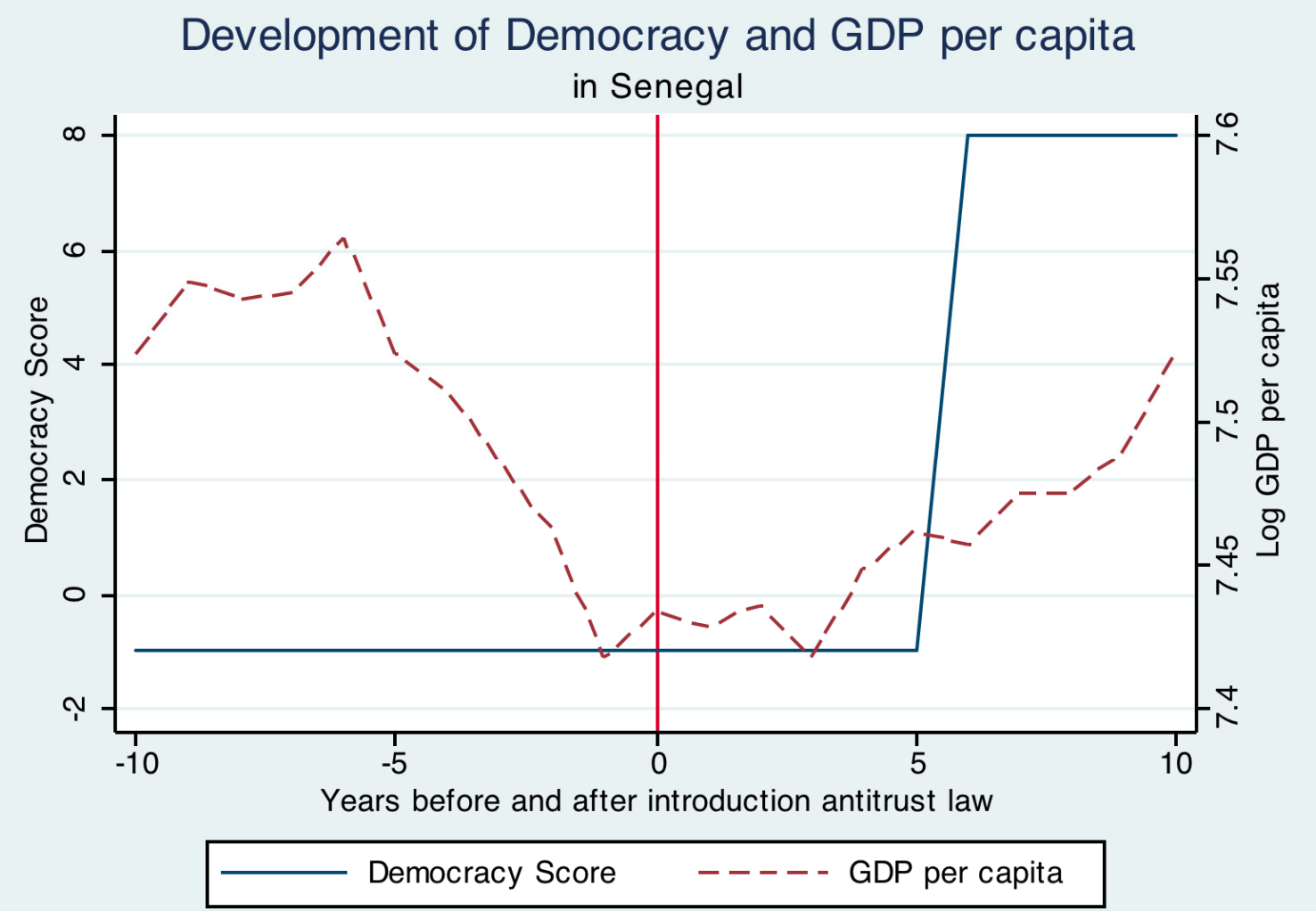




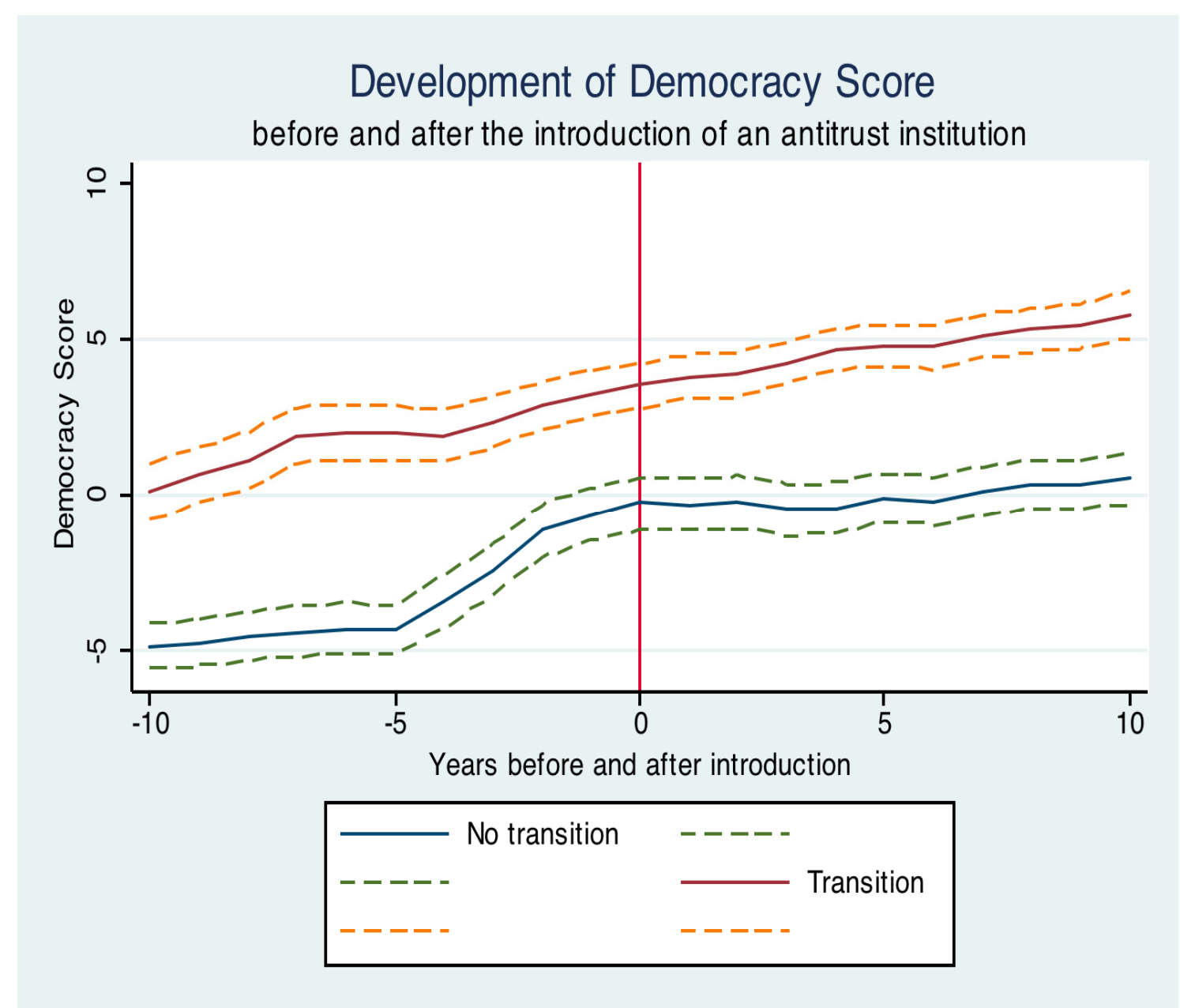

Note: The Graph compares the development of the democracy score of countries that introduced an antitrust law during the observation period from 1960 to 2007 with those countries that do not have an antitrust law up to date. For the states introducing an antitrust law (transition), year zero is the year in which the antitrust law was introduced. For the states that have not yet introduced an antitrust law to date, year zero is 1994, the median year of the introduction of antitrust laws in the data set. 
Figure 5: Development of GDP per capita

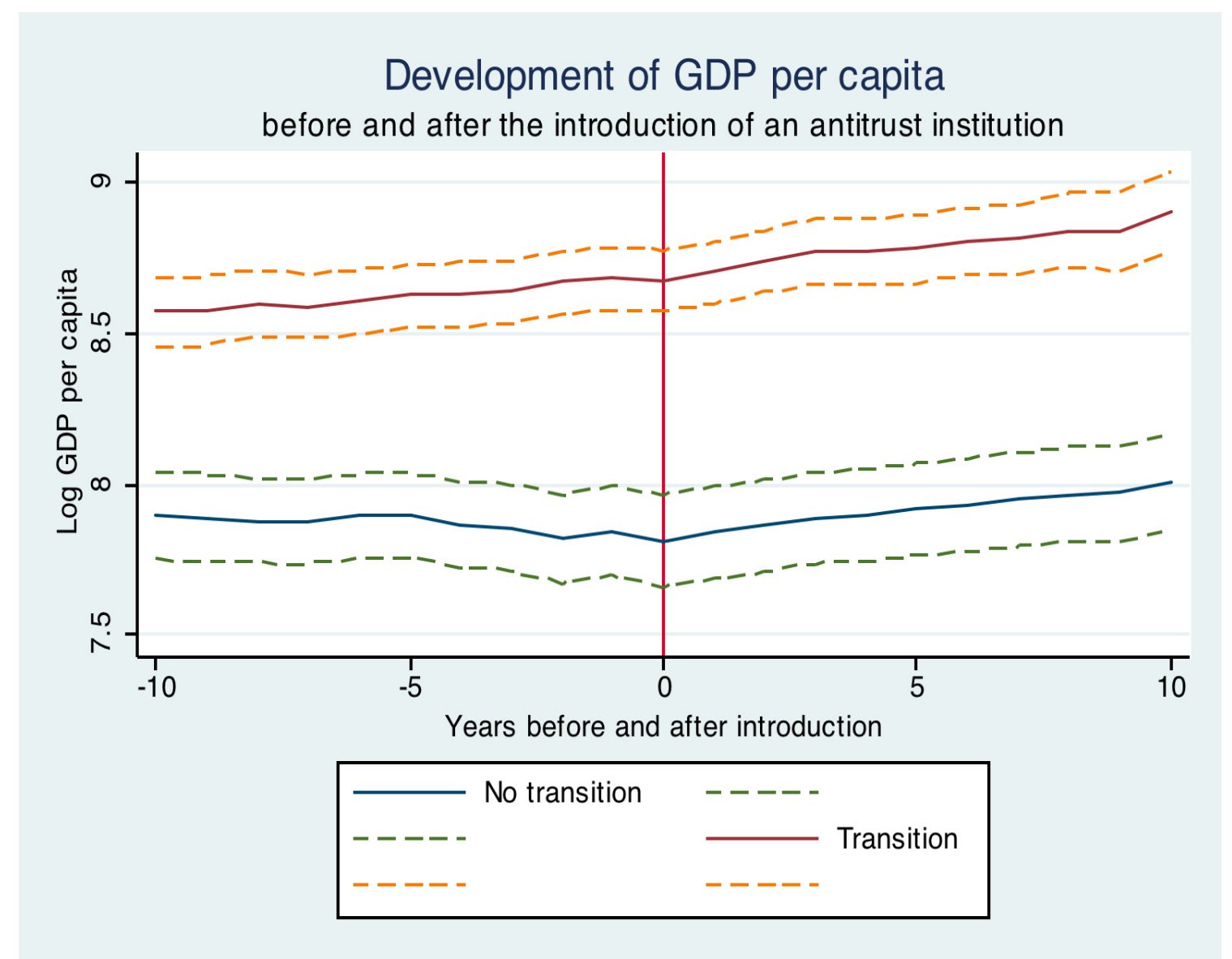

Note: The Graph compares the development of the log GDP per capita of countries that introduced an antitrust law during the observation period from 1960 to 2007 with those countries that do not have an antitrust law up to date. For the states introducing an antitrust law (transition), year zero is the year in which the antitrust law was introduced. For the states that have not yet introduced an antitrust law to date, year zero is 1994, the median year of the introduction of antitrust laws in the data set. 


\section{References}

Acemoglu, Daron, Simon Johnson, James A. Robinson and Pierre Yared (2008). "Income and Democracy". American Economic Review 98: 808-42

Acemoglu, Daron and James A. Robinson (2006). Economic Origins of Dictatorship and Democracy, New York: Cambridge University Press

Adams, Walter (1979). "Antitrust and a Free Economy". In Industrial Concentration and the Market System: Legal, Economic, Social, and Political Perspectives, ed. Eleanor M. Fox and James T. Halverson. Chicago: American Bar Association, 33-44

Akman, Pinar (2009). "Searching for the Long-Lost Soul of Article 82EC". Oxford Journal of Legal Studies 29: 267-303

Almond, Gabriel Abraham and Sidney Verba (1963). The Civic Culture: Political Attitudes and Democracy in Five Nations, Princeton: Princeton University Press

Amato, Giuliano (1997). Antitrust and the Bounds of Power: The dilemma of liberal democracy in the history of the Market, Oxford: Hart

Baker, Jonathan B. (2003). "The Case for Antitrust Enforcement". Journal of Ecomomic Perspectives 17: $27-50$

Barnes, David W. (1989). "Nonefficiency Goals in the Antitrust Law of Mergers". William \& Mary Law Review 30: 787-866

Barro, Robert J. (1996). "Democracy and Growth". Journal of Economic Growth 1: 1-27 (1999). "Determinants of Democracy". Journal of Political Economy 107: 158-83

Blake, Harlan M. (1973). "Conglomerate Mergers and the Antitrust Laws". Columbia Law Review 73: 555-92

Bogdandy, Armin von (2001). "Demokratisch, demokratischer, am demokratischsten? Zur Steigerungsfähigkeit eines Verfassungsprinzips am Beispiel einer Neugestaltung der Verordnungsgebung". In Verfassung - Philosophie - Kirche. Festschrift für Alexander Hollerbach zum 70. Geburtstag, ed. Joachim Bohnert et al. Berlin: Duncker \& Humblot, 364-84

Boix, Carles (2003). Democracy and Redistribution, New York: Cambridge University Press

Boix, Carles and Susan C. Stokes (2003). "Endogenous Democratization". World Politics 55: $517-49$

Bollen, Kenneth A. (1979). "Political Democracy and the Timing of Development". American Sociological Review 44: 572-87 
Bollen, Kenneth A. and Robert W. Jackman (1985). "Economic and Noneconomic Determinants of Political Democracy in the 1960s". Research in Political Sociology 1: 27-48

Bork, Robert H. (1993). The Antitrust Paradox: A Policy at War with Itself, New York: Basic Books

Bueno De Mesquita, Bruce, James D. Morrow, Randolph M. Siverson and Alastair Smith (2002). "Political Institutions, Policy Choice and the Survival of Leaders". British Journal of Political Science 32: 559-90

Burhop, Carsten and Thorsten Lübbers (2009). "Cartels, Managerial Incentives, and Productive Efficiency in German Coal Mining, 1881-1913". Journal of Economic History 69: 500-27

Carstensen, Peter C. and Nina H. Questal (1978). "The Use of Section 5 of the Federal Trade Commission Act to Attack Large Conglomerate Mergers". Cornell Law Review 63: 841-78

Claessens, Stijn, Simeon Djankov and Larry H.P. Lang (2000). "The separation of ownership and control in East Asian Corporations". Journal of Financial Economics 58: 81-112

Clement, Cynthia L., Andrew I. Gavil, Georges Korsun and William E. Kovacic (2001). Competition Policies for Growth: Legal and Regulatory Framework for SSA Countries, College Park: Institutional Reform and the Informal Sector, University of Maryland

Crandall, Robert W. and Clifford Winston (2003). "Does Antitrust Policy Improve Consumer Welfare? Assessing the Evidence". Journal of Ecomomic Perspectives 17: 3-26

Diamond, Larry (1992). "Economic Development and Democracy Reconsidered". In Reexamining Democracy. Essays in Honor of Seymour Martin Lipset, ed. Gary Marks and Larry Diamond. Newbury Park: Sage, 93-139

Diamond, Larry and Juan José Linz (1989). "Politics, Society, and Democracy in Latin America". In Democracy in Developing Countries: Latin America, ed. Larry Diamond, Juan José Linz and Seymour Martin Lipset. Boulder: Lynne Rienner Publishers, 1-58

Dutz, Mark A. and Aydin Hayri (2000). Does More Intense Competition Lead to Higher Growth?, Washington DC: World Bank Policy Research Working Paper

Dutz, Mark A. and Maria Vagliasindi (2000). "Competition policy implementation in transition economies: An empirical assessment". European Economic Review 44: 762-72

Epstein, David L., Robert Bates, Jack Goldstone, Ida Kristensen, Sharyn O'Halloran (2006). "Democratic Transitions". American Journal of Political Science 50: 551-69

Friedman, Milton (1962). Capitalism and Freedom, Chicago: University of Chicago Press 
Gal, Michal S. (2003). Competition Policy for Small Market Economies, Cambridge (Mass.): Harvard University Press

(2004). "The Ecology of Antitrust: Preconditions for Competition Law Enforcement in Developing Countries". In Competition, Competitiveness and Development: Lessons from Developing Countries, ed. UNCTAD. New York: United Nations, 20-38

Gerber, David J. (1994). "Constitutionalizing the Economy: German Neo-liberalism, Competition Law and the "New" Europe". American Journal of Comparative Law 42: 25-84

(2006). "Comparative Antitrust Law". In The Oxford Handbook of Comparative Law, ed. Mathias Reimann and Reinhard Zimmermann. Oxford: Oxford University Press, 1193224

Green, Chris (1987). "Industrial organization paradigms, empirical evidence, and the economic case for competition policy". Canadian Journal of Economics 20: 482-505

Harberger, Arnold C. (1964). "The Measurement of Waste". American Economic Review 54: 5876

Heston, Alan, Robert Summers and Bettina Aten (2009). Penn World Tables Version 6.3, Philadelphia: University of Pennsylvania

Hylton, Keith N. and Fei Deng (2007). "Antitrust around the world: An empirical analysis of the scope of competition laws and their effects". Antitrust Law Journal 74: 271-341

Kee, Hiau Looi and Bernard Hoekman (2007). "Imports, entry and competition law as market disciplines". European Economic Review 51: 831-58

Kosenko, Konstantin (2007). "Evolution of Business Groups in Israel: Their Impact at the Level of the Firm and the Economy". Israel Economic Review 5: 55-93

Krakowski, Michael (2002). Competition Policy Works: The Effect of Competition Policy on the Intensity of Competition - An International Cross-Country Comparison, Hamburg: HWWA Discussion Paper

La Porta, Rafael, Florencio Lopez-De-Silanes, Andrei Shleifer and Robert Vishny (1999). "The Quality of Government". Journal of Law, Economics \& Organization 15: 222

Lipset, Seymour Martin (1959). "Some Social Requisites of Democracy: Economic Development and Political Legitimacy". American Political Science Review 53: 69-105

Londregan, John Benedict and Keith T. Poole (1996). "Does High Income Promote Democracy?". World Politics 49: 1-30 
Lovdahl Gormsen, Liza (2007). "The Conflict between Economic Freedom and Consumer Welfare in the Modernisation of Art. 82 EC". European Competition Journal 3: 329-44

Marshall, Monty G. and Keith Jaggers (2009). Polity IV Project. Political Regime Characteristics and Transitions, 1800-2007, Severn: Center for Systemic Peace

Nicholson, Michael W. (2008). "An Antitrust Law Index for Empirical Analysis of International Competition Policy". Journal of Competition Law \& Economics 4: 1009-29

Palim, Mark R.A. (1998). "The worldwide growth of competition law: an empirical analysis". Antitrust Bulletin 43: 105-45

Persson, Torsten and Guido Tabellini (2006). "Democracy and Development: The Devil in the Details". American Economic Review 96: 319-24

- (2007). The Growth Effect of Democracy: Is it Heterogenous and how can it be Estimated?, Munich: CESIFO Working Paper

(2009). "Democratic Capital: The Nexus of Political and Economic Change". American Economic Journal: Macroeconomics 1: 88-126

Przeworski, Adam (1986). "Some Problems in the Study of the Transition to Democracy". In Transitions from Authoritarian Rule: Prospects for Democracy. Volume III: Comparative Perspectives, ed. Guillermo O'Donnell, Philippe C. Schmitter and Laurence Whitehead. Baltimore: The John Hopkins University Press, 47-63

Przeworski, Adam, Michael E. Alvarez, José Antonio Cheibub and Fernando Limongi (2000). Democracy and Development: Political Institutions and Well-Being in the World, 19501990, Cambridge: Cambridge University Press

Przeworski, Adam and Fernando Limongi (1997). "Modernization: Theories and Facts". World Politics 49: 155-83

Quack, Sigrid and Marie-Laure Djelic (2005). "Adaptation, Recombination, and Reinforcement: The Story of Antitrust and Competition Law in Germany and Europe". In Beyond Continuity: Institutional Change in Advanced Political Economics, ed. Wolfgang Streeck and Kathleen Thelen. Oxford: Oxford University Press, 255-81

Ross, Michael L. (1999). "The Political Economy of the Resource Curse". World Politics 51: 297-322

Sachs, Jeffrey D. and Andrew M. Warner (2001). "Natural Resources and Economic Development: The Curse of Natural Resources". European Economic Review 45: 827-38

Sartori, Giovanni (1987). The Theory of Democracy Revisited, Chatham: Chatham House 
Shapiro, Ian (2006). The State of Democratic Theory, Princeton: Princeton University Press

Sørensen, Georg (1998). Democracy and Democratization. Process and Prospects in a Changing World, Boulder: WestviewPress

Tilly, Charles (2007). Democracy, New York: Cambridge University Press

Tullock, Gordon (1967). "The Welfare Costs of Tariffs, Monopolies, and Theft". Western Economic Review 5: 224-32

Vanhanen, Tatu (1990). The process of democratization, New York: Crane Russak

Voigt, Stefan (2006). The Economic Effects of Competition Policy - Cross-Country Evidence Using Four New Indicators, Torino: ICER Working Paper

- (2009). "The Effects of Competition Policy on Development - Cross-Country Evidence Using Four New Indicators". Journal of Development Studies 45: 1225-48

Wagner, Stanley P. (1987). "Antitrust, the Korean Experience 1981-85". Antitrust Bulletin 32: $471-522$

Whish, Richard (2009). Competition Law, Oxford: Oxford University Press 